\title{
The Material Culture of Buddhist Propagation: Reinstating Buddhism in Early Colonial Seoul
}

\author{
Seunghye Lee
}

check for updates

Citation: Lee, Seunghye. 2021. The Material Culture of Buddhist Propagation: Reinstating Buddhism in Early Colonial Seoul. Religions 12: 352. https://doi.org/10.3390/rel 12050352

Academic Editor: Hiroko Kawanami

Received: 16 April 2021

Accepted: 7 May 2021

Published: 14 May 2021

Publisher's Note: MDPI stays neutral with regard to jurisdictional claims in published maps and institutional affiliations.

Copyright: (C) 2021 by the author. Licensee MDPI, Basel, Switzerland. This article is an open access article distributed under the terms and conditions of the Creative Commons Attribution (CC BY) license (https:// creativecommons.org/licenses/by/ $4.0 /)$.
Leeum, Samsung Museum of Art, Seoul 04348, Korea; seunghye.lee@gmail.com

\begin{abstract}
The restrictive measures against Buddhism under the Neo-Confucian Chosŏn dynasty resulted in the decline of Korean Buddhism at the start of the twentieth century. As the Chosŏn government started to make sweeping changes in the name of modernization, Korean Buddhist monks found an opportunity to revitalize their tradition through measures of reform. This paper examines one instance of attempts to bring Korean Buddhism back to the center of the country in the early twentieth century. The establishment of the Buddhist Central Propagation Space in 1920, examined thoroughly for the first time in this study, shows a meaningful yet ultimately unsuccessful attempt at modernizing Korean Buddhism in the dynamics of the colonial Buddhism. Moving beyond the nationalist critique of its founder Yi Hoegwang, who has been heavily criticized for his pro-colonialist undertakings in later historiography, I reconsider the significance of this propagation space in the history of Buddhist propagation and respatialization of Seoul during the early colonial period. My analysis of Three Gates in a Single Mind commissioned for this urban Buddhist temple in 1921 not only shows the diversity of modern Korean Buddhist paintings but also reveals a new role assigned to Buddhist icons in the changing context of Pure Land practice. I also discuss the seminal contribution of the court lady Ch'ŏn Ilch'orng to the founding of the propagation space, thereby restoring the voice of one important laywoman in the modernization of Korean Buddhism.
\end{abstract}

Keywords: colonization; Korean Buddhist painting; lay Buddhism; modern Korean Buddhism; propagation; Pure Land practice; Seoul; urban transformation

\section{Introduction}

Unlike other major cities in East Asia, Hansŏng 漢城, the royal capital of Chosŏn 朝 鮮 (1392-1910), was devoid of Buddhist temples since the mid-seventeenth century due to the dominance of Neo-Confucianism and the ban prohibiting Buddhist monks from entering the capital. The lack of Buddhist edifices and activities created a unique urban landscape, causing nineteenth-century Western travelers to wonder if Koreans had any religion at all (Walraven 2000, pp. 178-79). The religious and architectural landscape of the capital underwent rapid, large-scale transformation as a result of Korea's opening of her ports to foreign powers in 1876. Such changes only accelerated amidst the capital's transformation first into the "Imperial City" (Hwangsŏng 皇城) of the Great Han Empire (Taehan Cheguk 大韓帝國) and then into the colonial city Kyŏngsŏng 京城 during the Japanese occupation (Kim 2009; Yŏm 2016). As Todd A. Henry has shown, many social groups participated or intervened in the modern transformation of the city during this particularly turbulent period of Korean history (Henry 2007, 2014). The Korean Buddhist community was one of the forces that attempted to "respatialize" the capital with their agenda to bring Buddhism back to the center of the state and society. With the lifting of the ban in 1895, the Buddhist community found new opportunities to pursue meaningful reform and keep up with profound changes in Korean society and politics. ${ }^{1}$ Reinscribing Buddhism in Seoul was one of the primary goals of Korean Buddhist leaders. This goal was embodied in their strenuous efforts to establish a Korean Buddhist temple, one that would govern all temples in Korea, in central Seoul. 
Opportunities came with challenges, however. Korean Buddhism had to win over the lay public from Christianity, Japanese Buddhism, and indigenous new religions such as Ch'onndogyo 天道教 (The Religion of the Heavenly Way), while compromising first with the Korean Chosŏn government and later the Japanese colonial government. ${ }^{2}$ By 1911, a total of 167 Japanese Buddhist temples, branch temples (J. betsuin 別院), and propagation centers had been established on the Korean peninsula (Kim 1994, p. 20). By 1933, that number had grown to more than 350, with 1,900,000 lay believers (Kim 1933, pp. 14-15). ${ }^{3}$ Several attempts were made to establish the headquarters of Korean Buddhism within the city but failed due to the colonial government's regulations. Instead, these efforts led to the founding of propagation halls ( $p^{\prime}$ ogyodang 布教堂) in Seoul and other major cities. As Hwansoo Ilmee Kim and Mark A. Nathan have recently shown, the urban Buddhist temples were widely considered as advance bases for the propagation ( $p^{\prime}$ ogyo 布教) of Buddhist ideas and practices in the rapidly modernizing Korean society (H. Kim 2018, pp. 231-75; Nathan 2018, pp. 54-80). Along with Christian churches, Japanese Buddhist temples, and Shintō shrines, the branch centers of Korean Buddhist temples contributed to the hybrid character of the landscape of colonial Seoul by the late 1910s and early 1920s (Figure 1). Propagation halls were arenas for various forms of Buddhist propagation, ranging from regular dharma talks and public lectures to Sunday schools and ritual ceremonies such as weddings. Such halls were duly equipped with Buddhist icons, ritual tools, and other objects necessary for worship. In other words, the establishment of propagation halls brought the material culture of Buddhism back to cities.

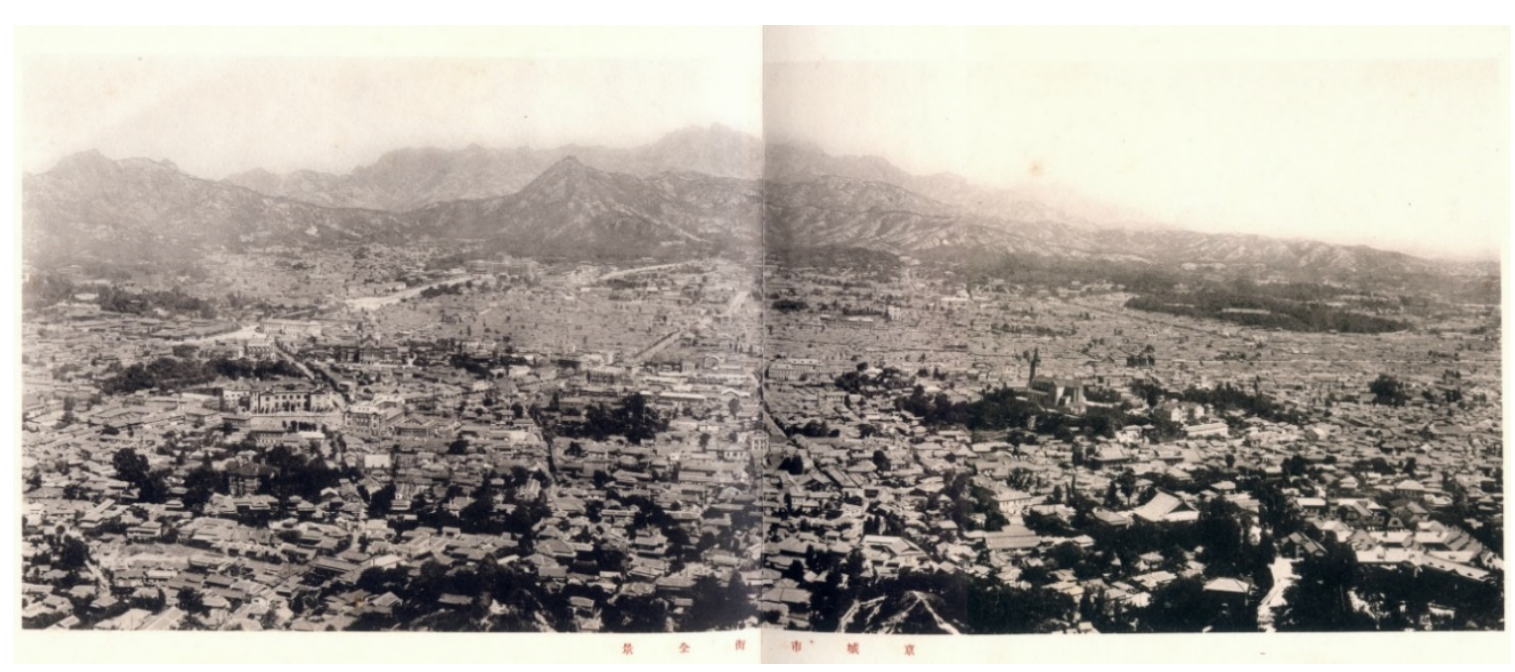

Figure 1. View of Seoul circa 1921. Sŏ 27618. After (Chōsen Sōtokufu 1921). Courtesy of Seoul Museum of History.

This article, through a case study of the Buddhist Central Propagation Space (Pulgyo Chungang P'ogyoso 佛教中央布教所) that stood in the former precinct of Tǒksugung 德 壽宮 in the 1920s but shortly faded into the mists of history, sheds new light on Korean Buddhism's efforts to secure a place in the state and society. The transformation of royal palaces into public spaces such as museums and public parks had taken place under the Japanese colonial authorities since the first decade of the twentieth century. ${ }^{4}$ However, the transformation of palace buildings into Buddhist edifices was still shocking to Seoul's residents in the early 1920s and, for this very reason, deserves sustained analysis. Thus, I will first examine the founding of the propagation space in the larger context of Korean Buddhist leaders' collective efforts-which were often marred by political discord-to reclaim Buddhism's place in the center of the country and to gain institutional governmentality. Then, I proceed to analyze the painting known to modern scholars as Three Gates in a Single Mind (Ilsim samgwanmun 一心三關門). Originally conceived as a triptych, the painting preserves the central and left frames only. Despite its fragmentary state, the painting is intriguing for its complex iconography that defies easy classification within the 
pre-developed canon of late Chosŏn Buddhist paintings. Currently housed in Simusa 尋 牛寺 in Kŏch'ang, South Kyŏngsang Province, the painting was examined in Choi Yeub's pioneering study on the role of Buddhist paintings and imagery in propagation during the early modern period (Ch'oe 2014a). Its unique iconography has also been subject to meticulous examinations in Kang Soyŏn's studies (Kang 2010, 2015). In the pages that follow, I reconsider the meaning of Three Gates in a Single Mind in the spatial context of this urban propagation space by raising some important questions. How did the painter create such a hybrid of iconography? Who were the intended viewers-cum-worshippers? Ultimately, what role did icons play in the effort to modernize Korean Buddhism? Answering these questions reveals hitherto unexamined aspects of the propagation space as lived religious space. In so doing, I bring the material culture of propagation halls to the fore while shedding new light on the religious aspirations of various social groups-ranging from Buddhist leaders to painters and lay believers-that have long remained obscure in the literature.

\section{Reinscribing Korean Buddhism in Seoul: The Founding of a Propagation Space}

At the start of the twentieth century, the Korean Buddhist community attempted to modernize Korean Buddhism through a variety of reformist measures. These reformminded Buddhists aspired to establish a powerful institutional structure, whether it be a central administrative office or a great head temple (H. Kim 2018, p. 187). The first propagation hall emerged amidst Korean Buddhism's efforts to form a modern and semiautonomous institution. In 1899, the royal court of Chosŏn established a small temple, later called Wŏnhŭngsa 元興寺, directly outside the Great East Gate of Seoul. In 1902, the Chosŏn government set up an administrative office there called the Bureau of Temple Administration (Sasa Kwalli Sŏ 寺社管理署) and promulgated the Temple Ordinance to regulate Korean Buddhism, designating Wŏnhŭngsa as the great head temple of the sixteen head temples in the provinces (Kwŏn 1917, p. 247). However, the temple, the office, and the system were short-lived as Japan seized control over Korea in the aftermath of the Russo-Japanese War (1904-1905). The headquarters of Korean Buddhist temples fell into the hands of Japanese Jōdōshū 淨土宗 briefly in 1906 but was returned to Korean Buddhist monastics in early 1908. Korean Buddhist leaders established Wŏnjong 圓宗, the first representative body of Korean Buddhism, and set up an administrative office at Wŏnhŭngsa (Yi 1918, vol. 2, p. 937). Yi Hoegwang 李晦光 (1862-1933), a monk who became heavily criticized by his contemporaries and later historians for his pro-colonialist undertakings, was designated as head priest of the sect (Figure 2)..$^{5}$ A significant account of his early life is included in Pŏmhae Kagan's 梵海覺岸 (1820-1896) Tongsa yŏlchŏn 東師列傳 (Biographies of Eastern Masters), completed in 1894. Ordained under the guidance of Poun Kŭngyŏp 寶 雲亘葉 at Sinhŭngsa 新興寺 in 1881, Yi Hoegwang earned a reputation as a great scholarly teacher (taegangbaek 大講伯) with whom young monks from all corners of the kingdom sought to study. ${ }^{6}$ Having traveled and practiced Sŏn meditation at various temples, he came to Seoul and soon found supporters among influential Buddhist monks who were well connected to the royal court and the Japanese Jōdōshū. 


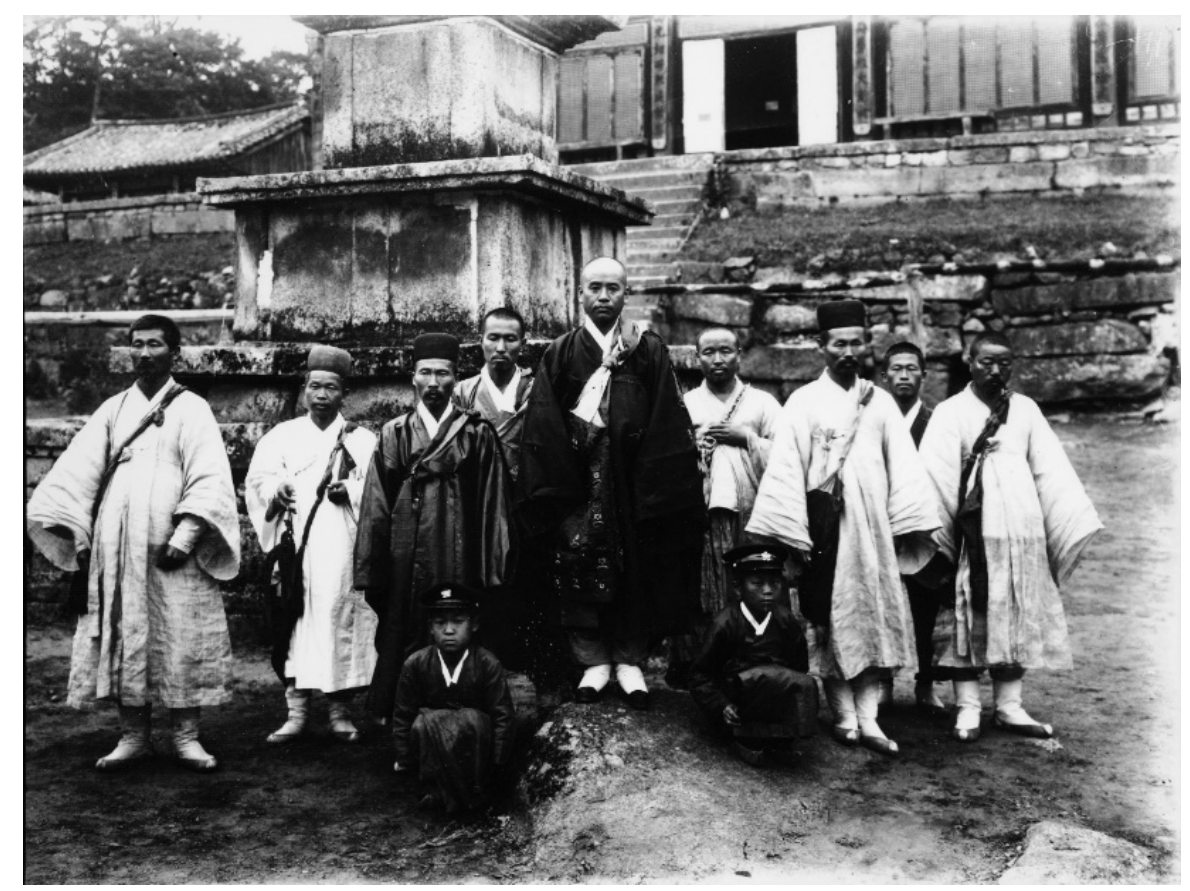

Figure 2. Yi Hoegwang (center) and leading monks of Haeinsa in 1910. Print from dry plate. Kŏnp'an 550. Courtesy of National Museum of Korea.

Establishing Korean Buddhism's future head temple within the four gates of Seoul was tremendously significant for Korean Buddhist monks. Located outside the wall, which had long separated Buddhist monks from the monarch and upper echelon, Wŏnhŭngsa was deemed inappropriate by Korean Buddhist leaders to serve as the great head temple. For them, the physical location seemed to signify a marginalized role for Korean Buddhism in society (Kim 2012, pp. 128-29). Such aspirations must have felt urgent, given that Christian and Japanese religious edifices had already been established within the walls of Seoul and other major cities. For instance, the first American Methodist church, constructed from 1895 to 1897, stood at Chŏngdong 貞洞, where the main palace Tŏksugung was located and foreign legations were concentrated (Figure 3). Typically, Japanese Buddhist missionaries established facilities for propagation in downtown areas near Japanese concessions in major treaty ports such as Pusan 釜山, Inch'ŏn 仁川, Mokp'o 木浦, and Kunsan 群山 (Kim et al. 2012, p. 59). For example, in 1890 the Ōtani branch of the Jōdō Shinshū 淨土眞宗 established a propagation space一affiliated with the Higashi Honganji 東本願寺 in Kyoto, Japan—right next to the Japanese legation on the northern slope of Seoul's Mount Nam 南 山. It was promoted to a branch center in 1895. Construction of its main hall was completed in May 1906 in the style of traditional Japanese temple architecture (Kim 1994, pp. 139-40) (Figure 4). ${ }^{7}$ The scenery of the area was further transformed as the Great Shrine of Mount Nam (Nanzan Daijingu 南山大神宮), renamed Keijō Jinja 京城神社 in 1916, was established in 1898.

Construction of these religious edifices introduced new types of architectural vocabulary hitherto unknown in Korea, transforming the skyline of Seoul and other major cities across the peninsula. Although Japanese Buddhist temples in Seoul were demolished in the post-colonial period, a couple of examples still remain in the southern parts of the peninsula. Like any ordinary Buddhist temples in Japan, they generally consisted of a main hall (J. hondō 本堂), where images of buddhas and bodhisattvas were enshrined, and a kitchen-residence (J. kuri 庫裡), where the abbot lived with his family. The main halls of Japanese Buddhist temples, as in the case of the Seoul branch of Higashi Honganji, was recognizable even from a distance due to its distinctive hip-and-gable roof construction (J. irimoya-zukuri 入母屋造). Roofed staircases were mostly installed at the center of such buildings' façades (Kim et al. 2012, pp. 62-71). 


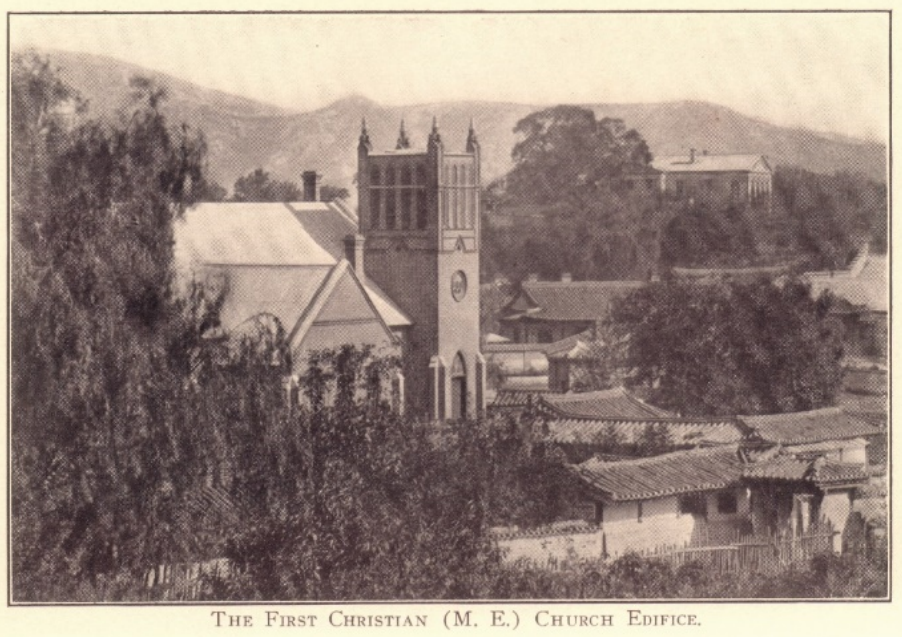

Figure 3. The First Christian Church at Chŏngdong in central Seoul, circa 1912. Sŏ 16943. After (Griffis 1912). Courtesy of Seoul Museum of History.

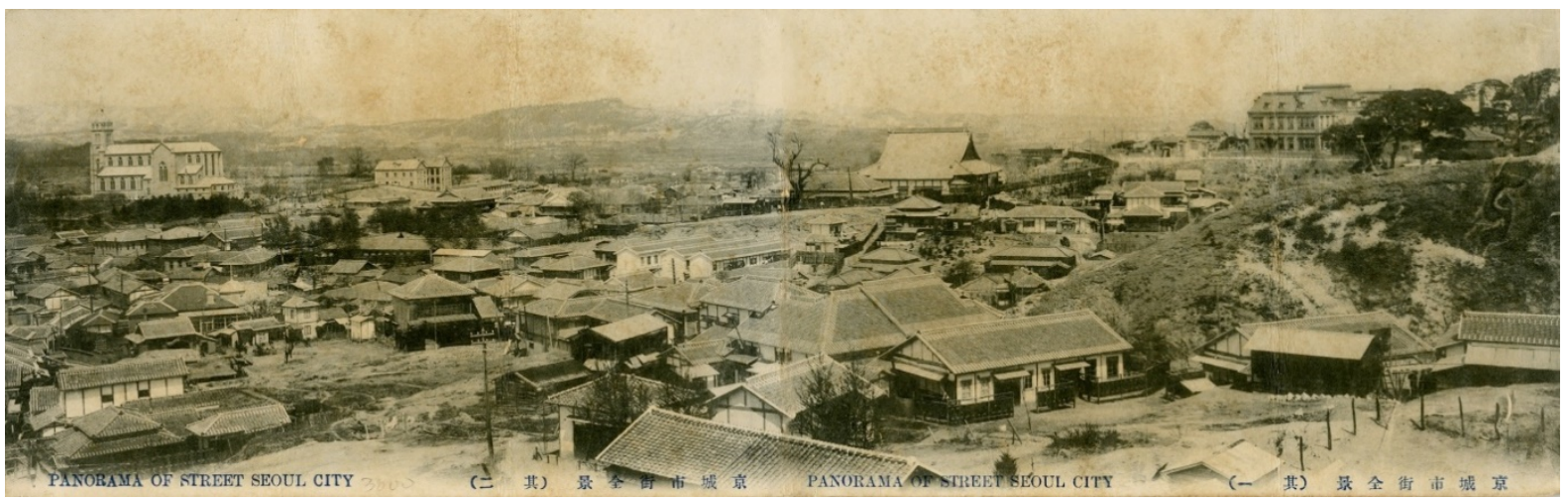

Figure 4. Panorama of Seoul showing the Japanese settlement on Mount Nam. Postcard. Dates unknown. Courtesy of Seoul Museum of History.

In late 1910, the leadership of Wŏnjong was able to build a new temple, Kakhwangsa 覺皇寺, inside the four gates of Seoul, and declared it to be the administrative center of Korean Buddhism. Given that Yi Hoegwang highly prized the propagation method of Japanese Buddhism, it is not surprising that he hired a Sōtōshū 曹洞宗 missionary to serve as an architectural consultant rather than following the traditional Korean architectural style. The temple was modeled after a branch temple of the Sōtōshū in central Seoul, despite fierce opposition from many Korean Buddhist monks. ${ }^{8}$ Shortly after, Yi Hoegwang and his colleagues went a step further in an effort to press authorities to recognize Wŏnjong. In October 1910, he attempted to merge the Wŏnjong with the Sōtōshū, infuriating many Korean Buddhist monks. ${ }^{9}$ For the rest of the Korean Buddhist community, it meant that the Sōtōshū, merely one of many sects of Japanese Buddhism, would annex the Wŏnjong, which represented Korean Buddhism in its entirety. Led by the well-known reformist monk Han Yong'un 韓龍雲 (1879-1944), this group of Korean Buddhist monks soon established a counter institution under the name of Imjejong 臨濟宗, setting up their own administrative office in Seoul in May 1912 (Kim 1995). The colonial government had disestablished both the Wŏnjong and Imjejong in 1911, ordering Korean Buddhists to adopt the institutional name Joint School of Sŏn and Kyo (Sŏn Kyo Yangjong 禪教兩宗). In June of 1911, the colonial government promulgated the Temple Ordinance (sach'allyŏng 寺刹令) in order to supervise the Korean Buddhist community directly under its administration (T. Han 2006, 
pp. 97-121). Under this legal framework, the founding of Korean Buddhist temples was denied but that of Buddhist propagation halls was permitted. Kakhwangsa, demoted to a propagation hall of Wŏnhŭngsa under the 1911 Temple Ordinance, became the first of its kind in central Seoul (Kim 2003).

From the 1910s, prominent Buddhist temples began to establish branches as propagation halls in cities and towns nationwide to disseminate the Korean Buddhist teachings and practices among the masses. By 1913, thirteen propagation halls had been established in Seoul by head temples across the country (H. Kim 2018, p. 236). The major propagation halls played a crucial role in monastic affairs and social movements as well, whereas the more modest ones still helped to give Korean Buddhism a foothold in modern society. The Buddhist Central Propagation Space appears to have been one of the most famous, if not successful, propagation halls. In retrospect, this was a byproduct of Yi Hoegwang's second alliance attempt in 1920. Yi Hoegwang attempted to merge Korean Buddhism with the Myōshinji 妙心寺 branch of the Japanese Rinzaishū 臨濟宗 in collaboration with the Rinzaishū missionary Gotō Tangan 後藤瑞岩 and the abbots of eight head temples in the South and North Kyŏngsang provinces. One of his key plans was to set up a great head temple in central Seoul. With the support of the eight head temples, Yi Hoegwang purchased a property in central Seoul as a possible site for the new main head temple (S. Yi 2004b, p. 194). As the Japanese newspaper Chügai nippō 中外日報 reported on his preparations for the alliance in June 1920, Yi Hoegwang soon drew harsh condemnation for attempting to sell out Korean Buddhism. ${ }^{10}$ In the end, he had to abort the deal since the colonial government found his plan to be in violation of the 1911 Temple Ordinance. Consequently, a propagation hall was set up on the purchased property in December 1920 instead of a great head temple. It was affiliated with Haeinsa 海印寺, a prominent temple in South Kyŏngsang Province with which Yi Hoegwang had been affiliated from around 1908 and where he served as abbot four times from December 1911 to 1924.

The founding and administration of the Buddhist Central Propagation Space drew intense public attention in the early 1920s for several reasons. At the beginning, newspapers focused on its location on the site of Sŏnwŏnjŏn 玷源殿, a part of Tŏksugung that had been extensively rebuilt since 1896 by Kojong 高宗 (1852-1919)—who ruled Korea as a Chosŏn king from 1864 to 1897 and as first emperor of the Great Han Empire from 1897 until his forced abdication in 1907 (Figure 5). ${ }^{11}$ Tŏksugung, once the political arena where Kojong declared the establishment of the empire, still held great significance for Koreans as the residence of the abdicated emperor until his death in January 1919. In the colonial period, the area encompassing the Sŏnwŏnjŏn and other buildings was popularly known as the palace precinct within the Yŏngsŏngmun (Yŏngsŏngmun taegwŏl 永成門大關) (Figure 6). The Sŏnwŏnjŏn, built in 1901 on the former sites of government drill grounds and private houses, held portraits of successive rulers of the Chosŏn dynasty, whereas other buildings in the precinct were used for royal funerary rites and ancestor worship (An 2009, pp. 227-31). ${ }^{12}$ As such, they collectively symbolized the legitimacy of the Great Han Empire and were greatly revered by Seoul's residents. Until Kojong's death in January 1919, the colonial government faced public opposition whenever it announced a new plan to develop the district (Y. Yi 2005a, p. 66). 


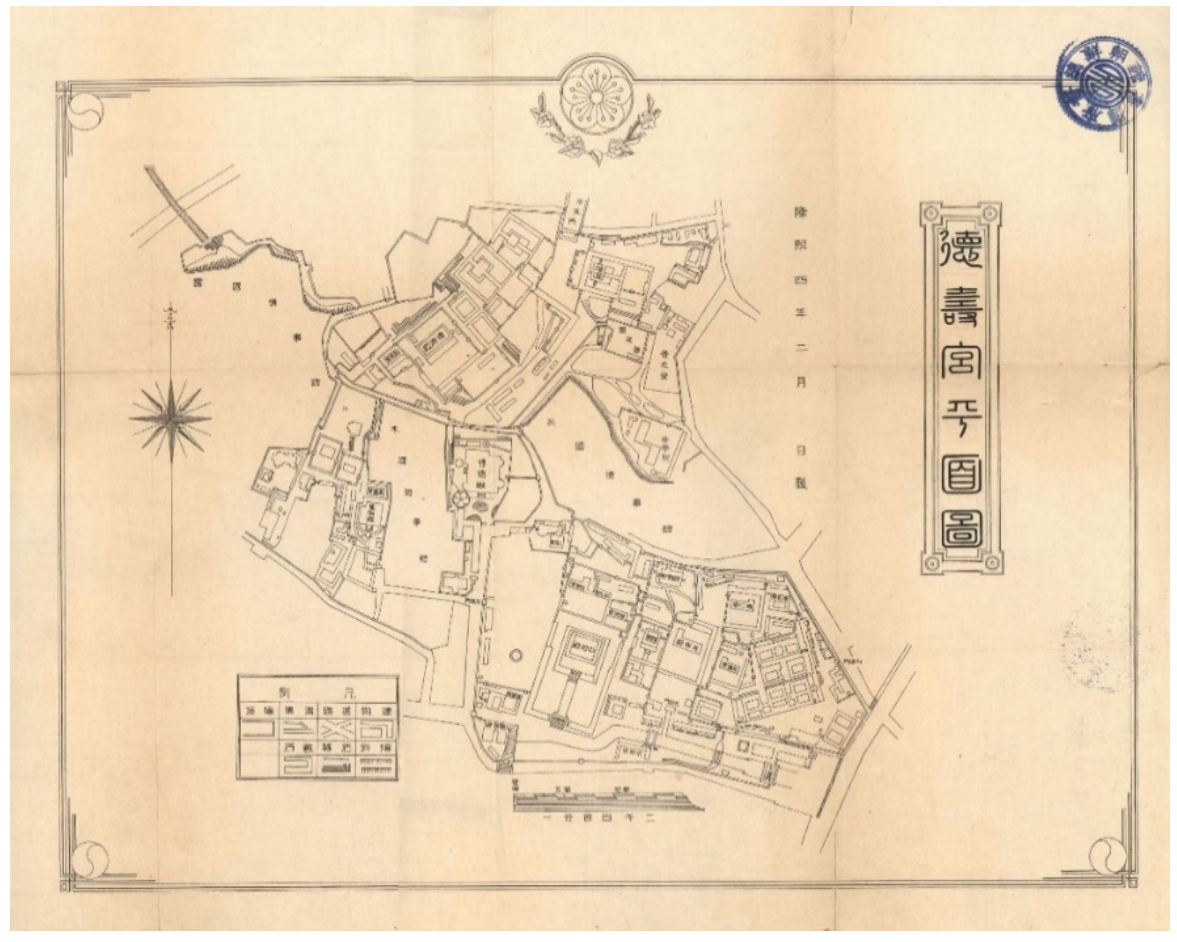

Figure 5. Plan of Tŏksugung in 1910. After (Oda 1938). Courtesy of National Library of Korea.

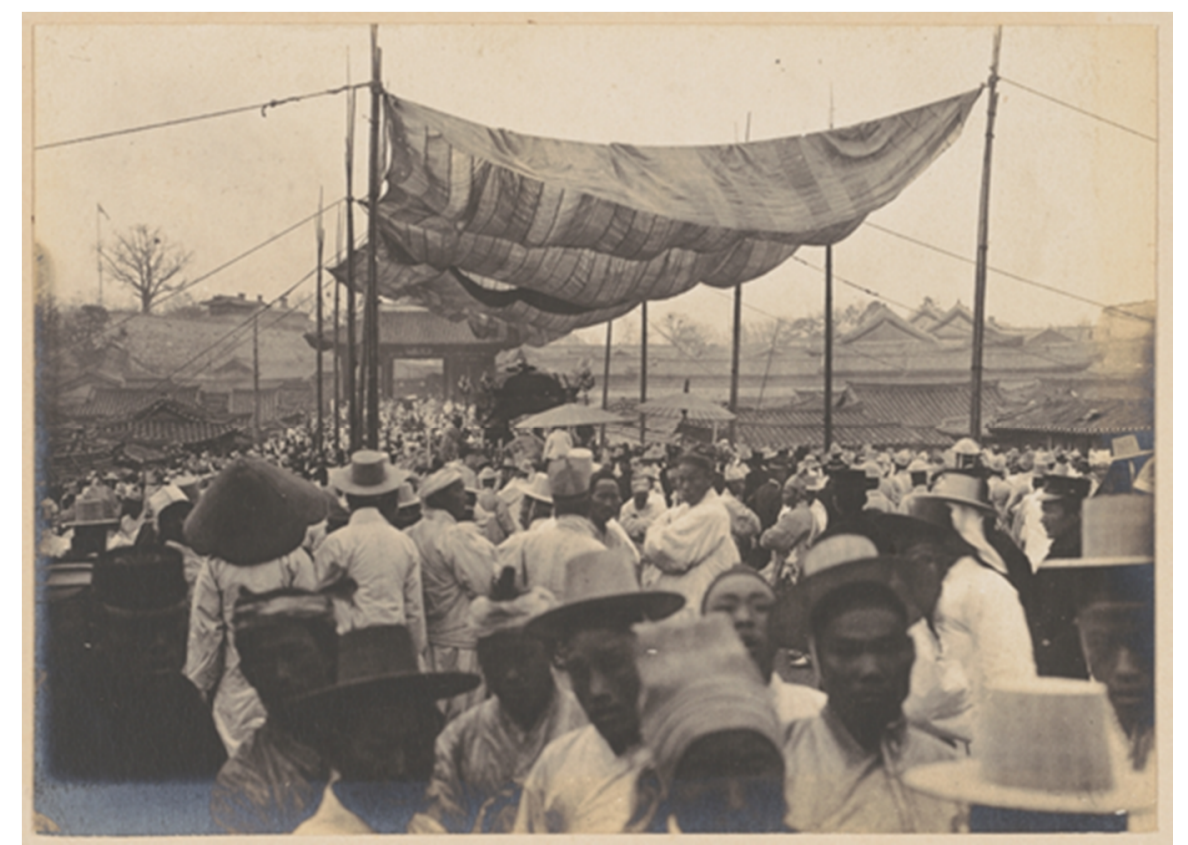

Figure 6. Yŏngsŏngmun (Min Yŏnghwan's state funeral procession). 1905. Photograph. Willard Dickerman Straight papers, \#1260. Courtesy of the Division of Rare and Manuscript Collections, Cornell University Library.

By January 1920, the Office of Prince Yi Household (Yiwangjik; J. Riōshoku 李王 職), which handled affairs regarding Korea's former royal house, appears to have made secret contracts to sell the vast expanse of 15,000 p'yŏng within the Yŏngsŏngmun to Japanese entrepreneurs under the pretense of efficient urban development, although it denied such deals in a newspaper interview. ${ }^{13}$ In fact, the dismantlement of the palace had already begun as late as the fall of $1919 .{ }^{14}$ Although the office repeatedly announced 
that this issue had not been discussed in February and March of $1920,{ }^{15}$ this explanation turned out to be false as evidenced by the demolition of palatial buildings within the Yŏngsŏngmun throughout the spring of that year (Y. Yi 2005b, pp. 159-60). ${ }^{16}$ As the royal portraits were relocated to Ch'angdŏkkung 昌德宮 in February 1920, major buildings within the Yŏngsŏngmun were dismantled and some of their materials were transferred to Ch'angdŏkgung to be used in the construction of the Sinsŏnwŏnjŏn 新玷源殿 for these portraits (K. Yi 2005). ${ }^{17}$ By May and June of 1920, the demolition was almost completed, causing much grief and anger among Koreans. ${ }^{18}$ A map of Seoul drafted in 1921 suggests that some ancillary buildings, which escaped demolition, were converted to facilities of the propagation space, while its main hall was constructed on the former site of Sŏnwŏnjŏn (Munhwajaechŏng 2014b, pp. 48, 59; Chang and Chŏn 2013, pp. 200-1; Chang 2014, pp. 184-85).

Yi Hoegwang, who secured 7,800 p'yorng of land in the spring of 1920, began preparations to open the "headquarters of propagation" (p'ogyo ponpu 布教本部) in Seoul, as the media dubbed it. ${ }^{19}$ Although the spatial arrangement of the establishment is not entirely clear due to lack of evidence, it had at least a main hall (Sambojŏn 三寶殿), a teaching hall (Sŏlpŏpchŏn 說法殿), and a meditation room (Sŏnsil 禪室) together with a five-storied stone pagoda and stone lantern. ${ }^{20}$ On 25 December 1920, the propagation space held a grandiose ceremony for the installation of a gilt Buddha statue that had been transported from its mother temple, Haeinsa, by train (Figure 7). ${ }^{21}$ The Buddha statue arrived at the Great South Gate Station of Seoul on the morning of the ceremony. Monks and lay believers, approximately one hundred in number, paid respects to the Buddha statue and escorted it to the newly built propagation space. The transportation of the statue from the station to the urban temple presented a spectacle to residents of Seoul. At the head of the procession were some ten flagbearers, followed by musicians playing horns and drums. Behind them was the statue, on a palanquin (yŏn 輦), followed by some twenty high-ranking monks, including Yi Hoegwang, and fifty lay believers. ${ }^{22}$ The installation ceremony was held at the Sambojön of the propagation space in the presence of honored guests, including eminent lay Buddhists such as Yi Nŭnghwa 李能和 (1869-1943) and colonial government officials. After the ceremony, monks and people at the temple threw "lucky cakes" (poktt'ók 복떡) to a crowd of a thousand people gathered in the temple precinct, as per the Japanese custom. ${ }^{23}$

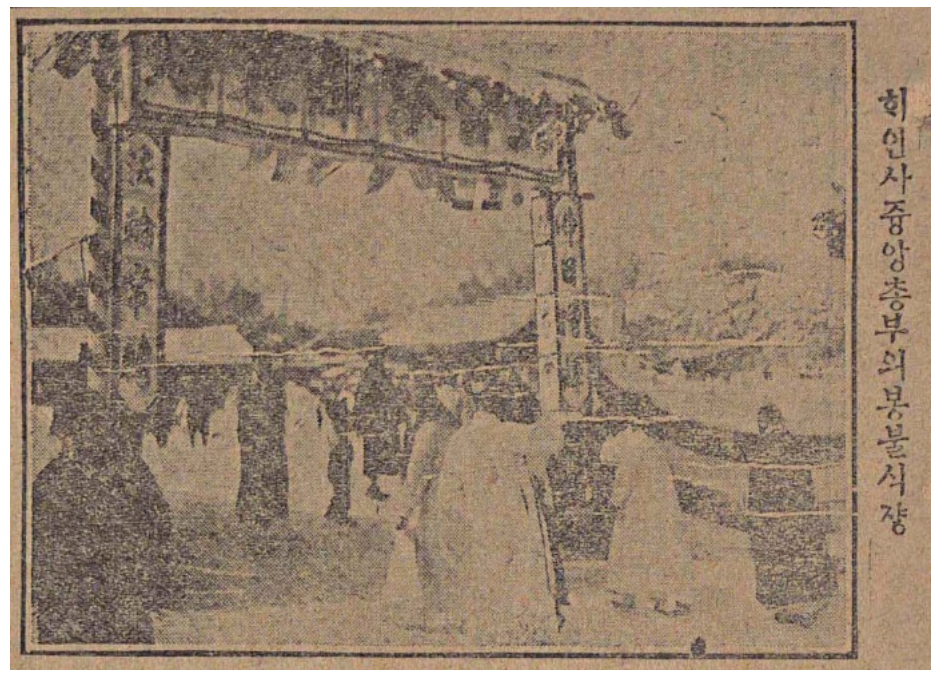

Figure 7. Central Headquarters of Haeinsa on the day of the Buddha Installation Ceremony. After Maeil sinbo, 26 December 1920. Courtesy of the National Library of Korea.

\section{Creating a Visual Emblem of Propagation: The Painting and Its Iconography}

Following the successful installation ceremony, the propagation space held an elaborate celebration for the birth of Buddha Śākyamuni in May 1921. The Buddha's Birthday, set for the eighth day of the fourth lunar month, was traditionally the climax of the Bud- 
dhist ceremonial year in Korea (Buswell 1993, p. 43). From the 1910s onward, the holiday was observed with elaborate events not only in major cities but also in remote mountain temples, thanks to new roads and mass transportation (H. Kim 2018, pp. 87-89). Several days before the Buddha's birthday, temples big and small typically hung banner paintings of monumental size ( $k$ waebul 掛佛) and lit round paper lanterns with beautiful tails (subak dŭng 수박등). Urban propagation halls also celebrated the long-awaited holiday with dharma talks and public lectures. ${ }^{24}$ For example, in 1920 the Kakhwang Propagation Hall held a celebratory lecture in the daytime and presented a play called Śăkyamuni's Triumph over Māra under the Bodhi Tree (Suha hangma sang 樹下降魔相) at night, attracting large numbers of lay people. ${ }^{25}$ Likewise, on May 13th and 15th of the following year, the Buddhist Central Propagation Space held public lectures and played a movie with Buddhist contents. ${ }^{26}$ The dedication of Three Gates in a Single Mind seems to have been a highlight of celebrations that the propagation space had planned.

Originally composed of three vertically elongated frames, the painting preserves the center and left frames intact as well as the ink inscriptions along its upper and left borders (Figure 8). The inscriptions, which can be classified into three groups, show a manner of writing a "painting record" (hwagi 畫記) quite different from the convention of late Chosŏn Buddhist paintings. First of all, the two inscriptions along the upper border identify the theme of each frame unfolding downwardly. The central frame portrays the "Nine grades of rebirth in the Land of Ultimate Bliss and the dragon boat of wisdom" (Küngnak kup'um panya yongsŏn 極樂九品般若龍船), a theme that became codified and popular in the late nineteenth century, whereas the left frame illustrates the "Rebirth in all the heavenly palaces as retribution for good deeds" (Chech'ŏn kungjŏn susŏn sangsaeng 諸 天宮殿修善上生). The theme of the right frame seems to have been identified in the same way although its composition is almost impossible to deduce since it is missing.

Next, the left border of the painting bears two groups of ink inscriptions, one identifying the overarching theme of the painting and another revealing crucial information about its production. The first group, in large characters, reads: "Three gates in a single mind. Cultivating the causes [of enlightenment] in yearning for retributions" (Ilsim samgwanmun. Mogwa suin. 一心三關門 慕果修因). ${ }^{27}$ The three gates, corresponding to the three frames that make up the painting, refer to entrances to the Land of Ultimate Bliss, or the Western Paradise of Amitābha Buddha, the most desired postmortem destination throughout the late Chosŏn and modern eras. The "causes" in the following line refer to good deeds, whereas "retribution" corresponds to rebirths in the Western Paradise. The opening of the inscription, "Three gates in a single mind," has become synonymous with the painting in modern scholarship.

The last inscription, written in small characters in the lower left of the border, reads:

Began on the first day of the third lunar month in the sinyu year, the 2948th year since the birth of Sākyamuni, the honored one. Reported its completion on the day of bathing the Buddha. Enshrined in the Sŏlpŏpchŏn of the Buddhist Central Propagation Space. Staff at the time. Supervisor Hoegwang Sasŏn. Verifier Podam Poha. General affairs Chisang Sesin. Religious affairs Hwaryŏn Segwan. Financial affairs Taeun Chonu. Composition Kosan Chukyŏn. Painters Haksong Hangnul and Ch'oam Sebok. Painters responsible for composition of the wisdom boat. Novice Chŏngsun and layman Yi Pyŏnggu

釋尊降誕二千九百四十八年辛西三月初一日起始 灌佛日告功仍奉安于 佛教中央 布教所說法殿内 當時職員 監督晦光師㹔 證明寶潭普荷 庶務智相世信 教務活淵 世觀 財務大雲尊雨 出草古山笙演 畫工鶴松學訥 草庵世復 般若船出草 畫工 淨順 沙彌 信士李秉球 


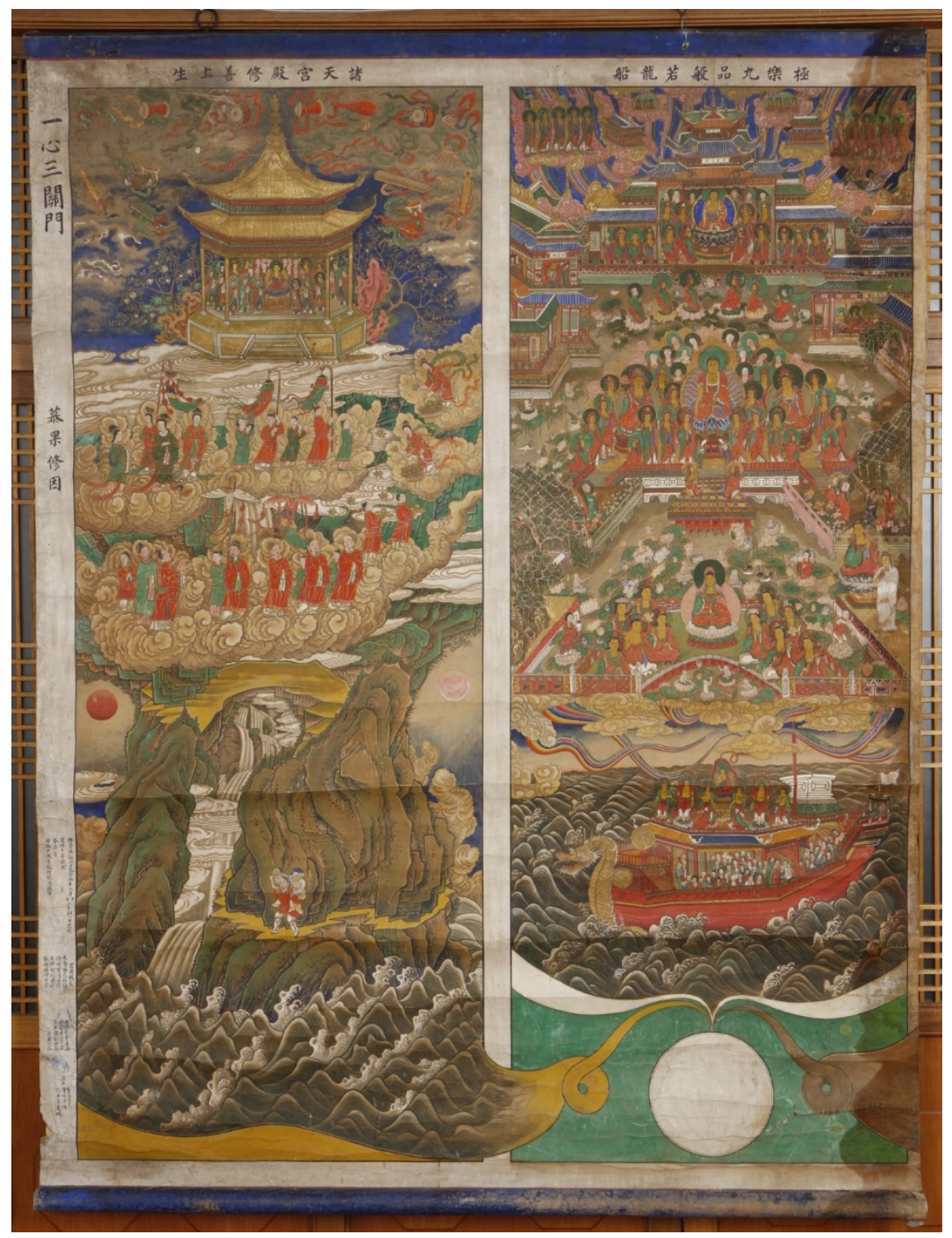

Figure 8. Ch'ukyŏn and others, Three Gates in a Single Mind. 1921. Colors on cotton, $217 \times 161.5 \mathrm{~cm}$. Simusa, Kŏch'ang, South Kyŏngsang Province. Photograph by Choi Yeub.

The painting was, according to the inscription above, enshrined in the Sŏlpŏpchŏn of the Buddhist Central Propagation Space on the day of bathing the Buddha (Kwanbul il 灌佛日) in 1921. The day, honoring the Buddha's birthday, corresponds to 15 May 1921 in the Gregorian calendar. The short inscription is illuminating in many respects for the organizational change that it witnessed. The typical votive inscription of a late Chosŏn Buddhist painting, written in cartouches along the lower border, begins with the part recording the date of production, the theme(s) and number of painting(s) being dedicated, and the location. The remaining portion of the inscription usually consists of three parts. The first part, called younhwa chil 緣化秩, records those who participated in and supported the production of painting from the post of verifier (chŭngmyŏng 證明) to the reciter of spells (songju 誦呪), director of affairs (chijŏn 持殿), painters (kümŏ 金魚), and fundraiser (hwaju 化主). ${ }^{28}$ This is followed by a portion called sanjung chil 山中秩, which lists resident monks of the temple where the painting will be enshrined. The last part, called siju chil 施主秩, records the names of patrons who financially supported the production. Sometimes, it is further followed by dedicatory wishes. Herein, traditional monastic duties are largely replaced by modern terms recalling secular corporate ones. Although we cannot 
be certain, the right border may have borne another piece of inscription listing the names of such patrons.

The inscription acknowledges Yi Hoegwang as the supervisor (kamdok 監督), seemingly corresponding to the post of togam 都監, which handles a temple's religious affairs as well as the logistics of construction and image production. It credits Kosan Ch'ukyŏn 古山筑衍 (ca. 1850-1930) as the monk painter responsible for the overall composition

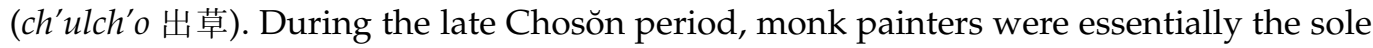
suppliers of Buddhist paintings and statues for temples. Traditionally, young novices would train in temples under master monk painters. Once they had become accomplished, they would begin to train their own apprentices in the same way. The disciples usually inherited ink drawings ( $c h^{\prime} o$ 草 or ch'obon 草本) of altar paintings and referred to them from time to time, even after becoming head painters. Consequently, the conservative nature of apprenticeship promoted the practice of copying from artistic models. The creation of plans for highly complex devotional images required deep knowledge of Buddhist iconography, skilled brushwork, and excellence in composition. Only accomplished monk painters, or those skilled in pictorial composition, designed new plans for devotional images (Chang and Wilson 2003, pp. 58-59).

Ch'ukyŏn was inarguably the only monk painter qualified for the daunting task of an original composition for the Sŏlpŏpchŏn. Surnamed Mun 文, he was active as a painter from the mid-1870s to 1930. Already accomplished as a head painter, Ch'ukyŏn returned to lay life around $1894 .{ }^{29}$ Based at Yujŏmsa 榆岾寺 in the Diamond Mountains as a lay Buddhist practitioner ( $k \breve{s s} a$ 居士), he seems to have made his living by producing paintings of secular subjects from around 1895 to 1910 (Ch'oe 2005, pp. 167-68). He then rejoined the samgha as a married Buddhist monk at the age of sixty around 1915. During the early colonial period, Ch'ukyŏn earned a reputation as a leading master of Buddhist paintings, with coverage in newspapers and early publications on Korean art. ${ }^{30}$ His fame increased in his later years to the extent that he was called "the head and model painter of the entire Korea” (chŏn Sŏn'gye subŏm hwasa 全鮮界首範畫師) (Hoemyŏng 1991, p. 363). His works dating after the 1910s, many of which were commissions for major temples, stand out for their novel iconography, dramatic compositions, and non-traditional painting techniques. It is notable that Ch'ukyŏn and Yi Hoegwang, serving as painter and verifier, respectively, collaborated on numerous projects involving the repair and production of Buddhist icons. From the 1900s to 1920s, they collaborated on several Buddhist paintings commissioned by major temples in North Kyŏngsang Province. For example, they participated together in the production of Buddhist paintings for Tonghwasa 桐華寺 in 1905, Sŏnsŏksa 禪石 寺 in 1918, and Taedunsa 大英寺 in 1920. ${ }^{31}$ Given that Yi Hoegwang supervised this painting's production, he may have commissioned Ch'ukyŏn to create a novel composition embodying his vision of propagation that would appeal to temple-goers of the time.

Judging from surviving sections of the inscriptions and painting, the piece as a whole seems to illustrate the theme of one mind generating three different effects in accordance with the three causes while also preaching that one must practice good deeds to earn rebirth in the Western Paradise. As such, the painting embodies a moral, encouraging believers to cultivate their mind and accumulate good karma for good retribution (Ch'oe 2014a, pp. 207-8). The tripartite composition would have been derived from the white circle against the bright green background at the bottom of the central frame. ${ }^{32}$ As mentioned earlier, the central frame portrays the two sub-themes-namely, the nine grades of rebirth and the salvific dragon boat-in a vertically elongated frame. On the one hand, the scriptural basis of the former theme is found in the Contemplation Sūtra (Kwan Muryangsu kyŏng 觀無量壽 經), which teaches sixteen kinds of meditation (sibyuk kwan 十六觀) as a means for attaining rebirth in the Western Paradise. The sixteen kinds of meditation, a popular iconographic theme of Buddhist paintings during the Koryŏ 高麗 (908-1392), gradually gave way to the theme of the nine grades of rebirth, corresponding to the fourteenth, fifteenth, and sixteenth meditations in the Contemplation Sütra. The motif of nine grades of rebirth, although it had already appeared in the late Koryŏ, developed into diverse forms and enjoyed wide 
popularity starting in the eighteenth century due to its strong visual effect of presenting the rebirth in lotus ponds (Chŏng 2007, p. 151). ${ }^{33}$ On the other hand, the dragon boat of wisdom refers to an iconographic motif in which Amitābha Buddha receives deceased souls and ferries them to his Western Paradise. The dragon, a protector of Buddhist law, is entrusted with the task of ferrying souls to the other shore. The motif, which dates back to the late thirteenth century, appears to have received heightened interest in the late nineteenth century to the extent of becoming an independent subject for altar paintings and murals in worship halls (C. Kim 2014a).

The rise of the two motifs was linked to the popularity of Pure Land cultic practices, particularly the verbal chanting of the name of Amitābha Buddha (yŏmbul 念佛), to attain rebirth in the Western Paradise among all social strata at the time (Lee 2019, p. 38). Shortcut to Rebirth through Buddha Mindfulness (Yŏmbul wangsaeng ch'ópgyoung to 念佛往生捷俓圖), painted in 1750 for the Simgŏmdang 尋劍堂 of Ünhaesa 銀海寺 in North Kyŏngsang Province, shows the amalgamation of these two themes in a single composition (Figure 9). ${ }^{34}$ Near the ornate railing that divides the painting in half, the upper right portion renders Amitābha Buddha preaching in his Western Paradise and the deceased souls being reborn in lotus blossoms in accordance with their respective spiritual capacities. A dragon boat boarded by the disembodied is shown approaching the land of ultimate bliss (Pulgyo Chungang Pangmulgwan 2016, pp. 176-77). A cartouche identifies this scene as "Those who practiced Buddha mindfulness boarding the ship and being reborn" (Yŏmbul chi in sŭngsŏn wangsaeng 念佛之人乘船往生), indicating that the verbal recitation of Amitābha Buddha's name was considered the simplest and most effective means to ascend to the Western Paradise.

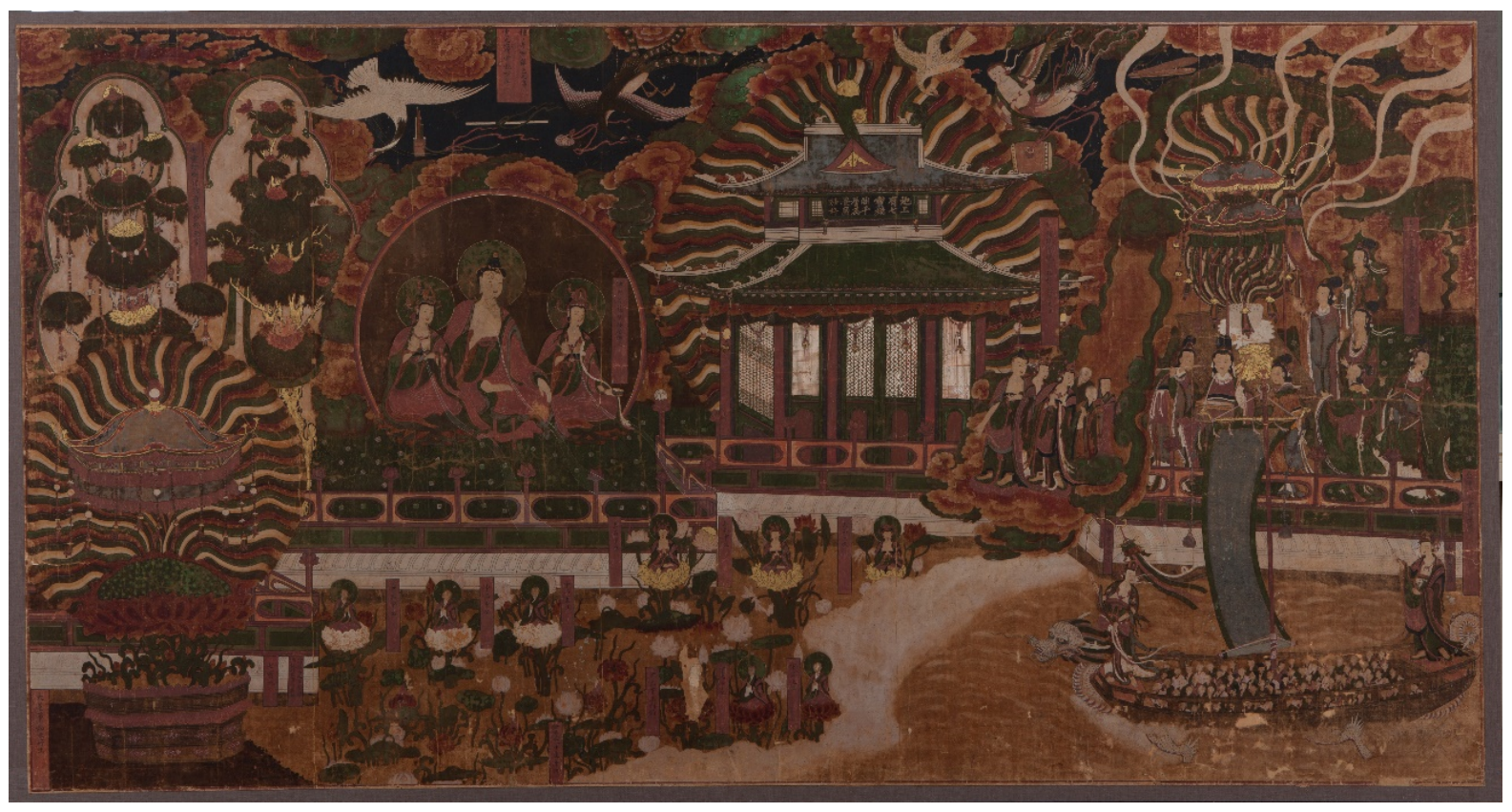

Figure 9. Shortcut to Rebirth through Buddha Mindfulness. Chosŏn, 1750 . Colors on silk. $159.8 \times 306.5$ cm. Ŭnhaesa, Yŏngch’ŏn, North Kyŏngsang Province. Courtesy of the Cultural Heritage Administration.

The combination of the two Pure Land themes is also found in a set of paintings that seems to have been created by Ch'ukyŏn in 1915 (Ch'oe 2010, pp. 196-97; Lee 2019, p. 48, 54). The paintings, hung in the main hall of Anyang'am 安養庵 outside the Great East Gate of Seoul, show a precedent for pairing the two themes but of a slightly different manner (Figure 10). In the Anyang'am set, the lower painting illustrates Amitābha Buddha and his attendant bodhisattvas ferrying souls of the disembodied on a dragon boat to the Western Paradise, whereas the upper one shows the souls having arrived and undergoing rebirth inside lotus flowers as they hear the sermon of Amitābha Buddha in his Pure Land 
(Lee 2019, pp. 48-51). Compared to the Anyang'am paintings, where the two themes are allotted separate frames, Ch'ukyŏn synthesized the two within a vertically elongated frame measuring more than 200 centimeters in height (Figure 8). The journey of deceased souls on board the dragon boat of wisdom to the Western Paradise unfolds above two beams of light that emanate from the top of the white circle. The lower half of the frame is devoted to a dragon boat, whose composition was drawn by the novice Chŏngsun 淨 順 (1901-?) of Haeinsa, crossing a dark sea of rolling waves (Figure 11). ${ }^{35}$ At the center of the dragon-headed boat stands a two-storied, hexagonal structure. Assembled on the second story are the Buddha and bodhisattvas, while the disembodied sit within the cabin below. Amitābha Buddha sits on a high pedestal raising his right hand before his chest. He is accompanied by six bodhisattvas, each of whom stands on a lotus pedestal. Two monks sit back to back, their hands raised in prayer. Inside the hexagonal structure are men and women of all ages.

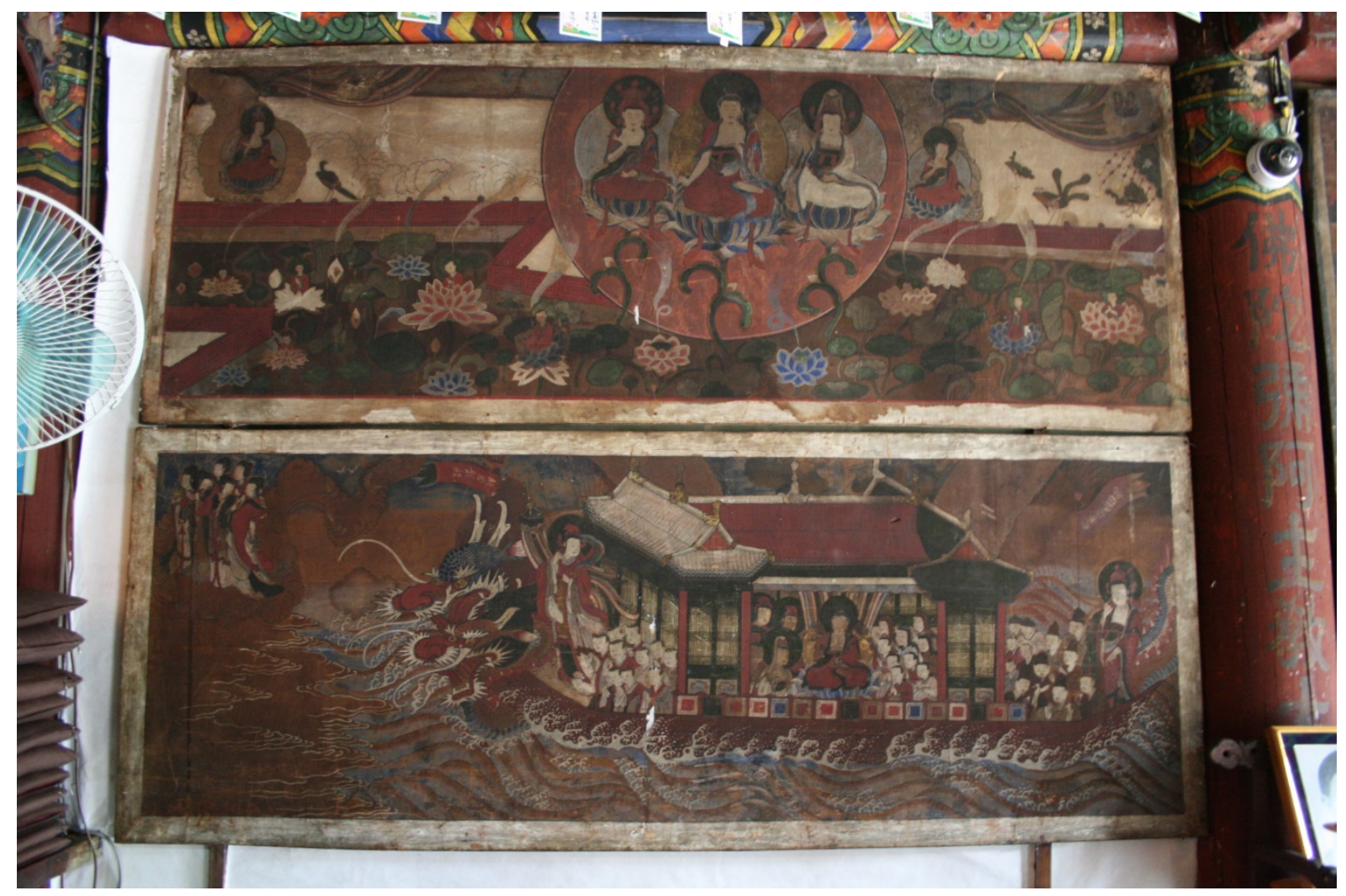

Figure 10. Amitābha's Pure Land, circa 1915. Colors on silk. $68.5 \times 203.0 \mathrm{~cm}$ each. Anyang'am, Seoul. Photograph by the author. 


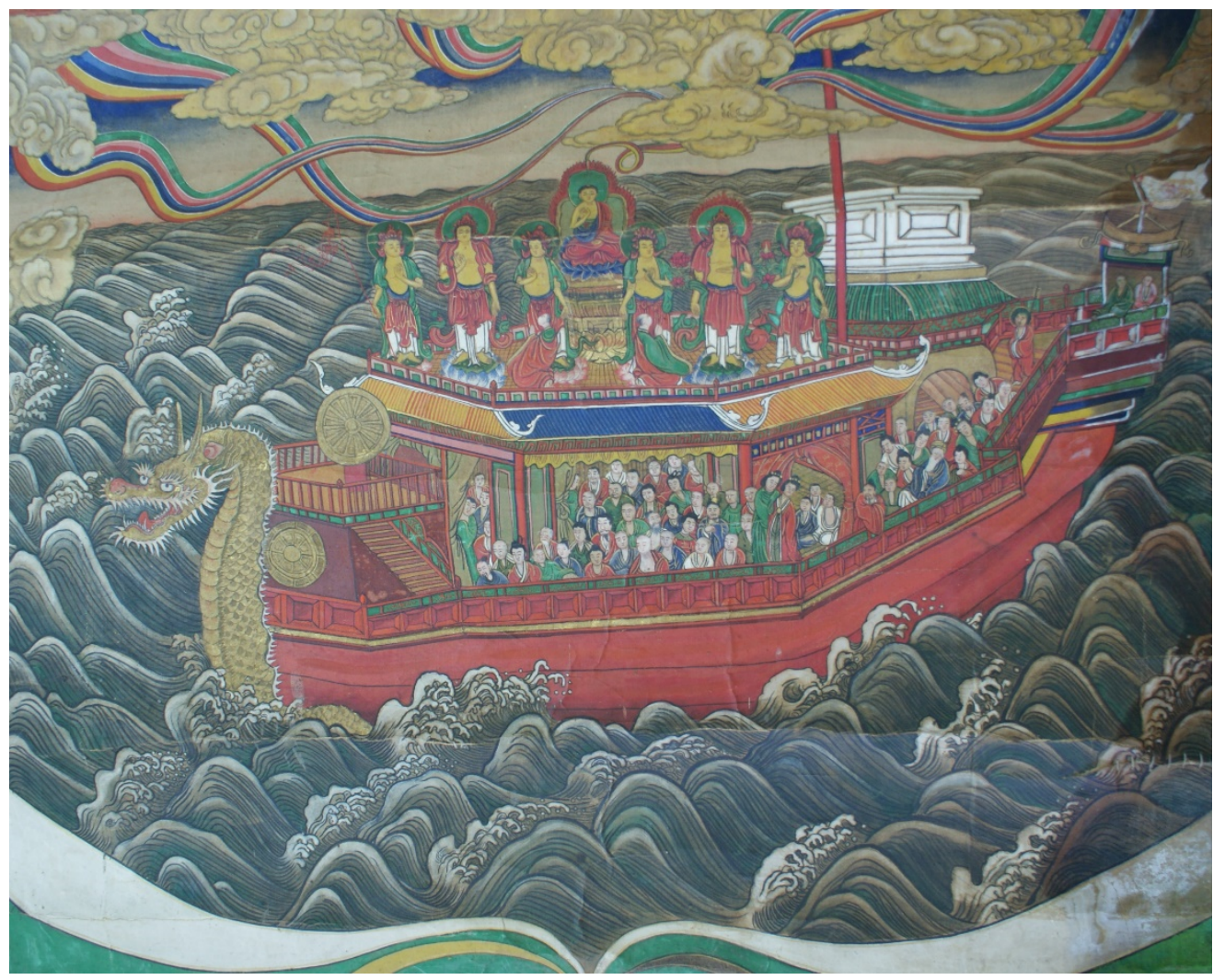

Figure 11. Detail of Three Gates in a Single Mind showing the salvific dragon boat in the central frame. Photograph by Choi Yeub.

The final destination of the disembodied awaits them in the upper portion. The dragon boat, as a result of the prismatic beams that meander from foreground to background, remains subtly linked to the heavenly palace in the clouds. Compositionally speaking, this section bears close resemblance not to paintings of the nine grades from the late nineteenth century but to the central section of paintings on the sixteen kinds of meditation from the late Koryŏ and early Chosŏn periods, attesting to the enduring vitality of this pictorial tradition (Kang 2010, p. 171). The composition introduces heavenly figures in ascending order of spiritual authority. A small pond, demarcated by a balustrade and clouds, contains four souls who have just been reborn in the Pure Land. Beyond them is Avalokiteśvara Bodhisattva surrounded by other bodhisattvas (Figure 12). Intriguingly, it recalls the bodhisattva of compassion appearing in a Chinese single-sheet print circulated among a group of monk painters in the early twentieth century. The Chinese print features the Monk Budai (P'odae hwasang 布袋和尚, fl. 10th century), venerated as Maitreya Buddha in Chan Buddhism, Kșitigarbha Bodhisttva, and Avalokiteśvara Bodhisattva aligned vertically with the three Buddhas on top (Figure 13). Despite some minor variations, the seated Avalokiteśvara Bodhisattva bears affinities to the one in the print in terms of the attributes in each hand and the hood over his topknot. ${ }^{36}$ To the right of the pond stands Avalokiteśvara Bodhisattva in a white robe (Paegŭi Kwanŭm 白衣觀音), one of the thirty-three forms of the bodhisattva that gained wide popularity in the late nineteenth and early twentieth centuries, with his hands clasped in prayer. 


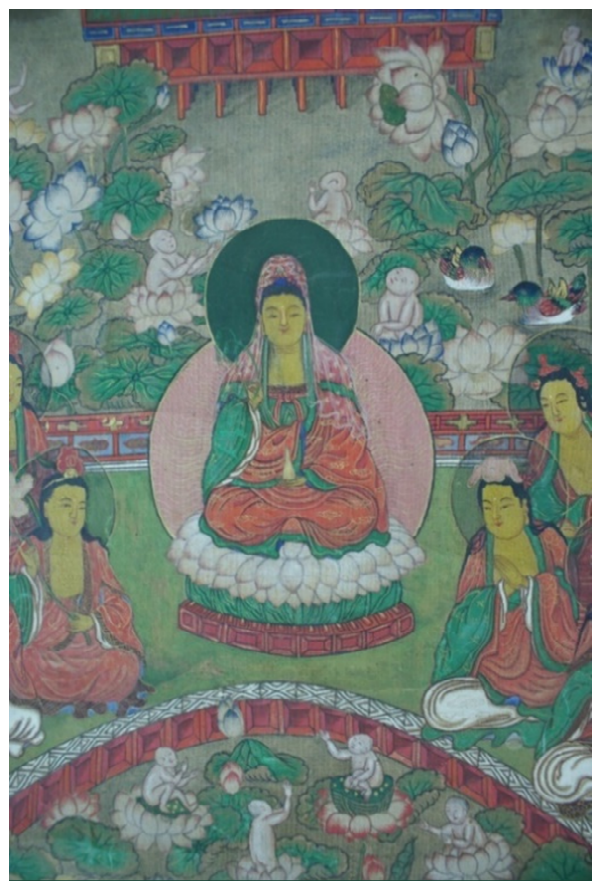

Figure 12. Detail of Three Gates in a Single Mind showing Avalokiteśvara Bodhisattva in the central frame. Photograph by Choi Yeub.

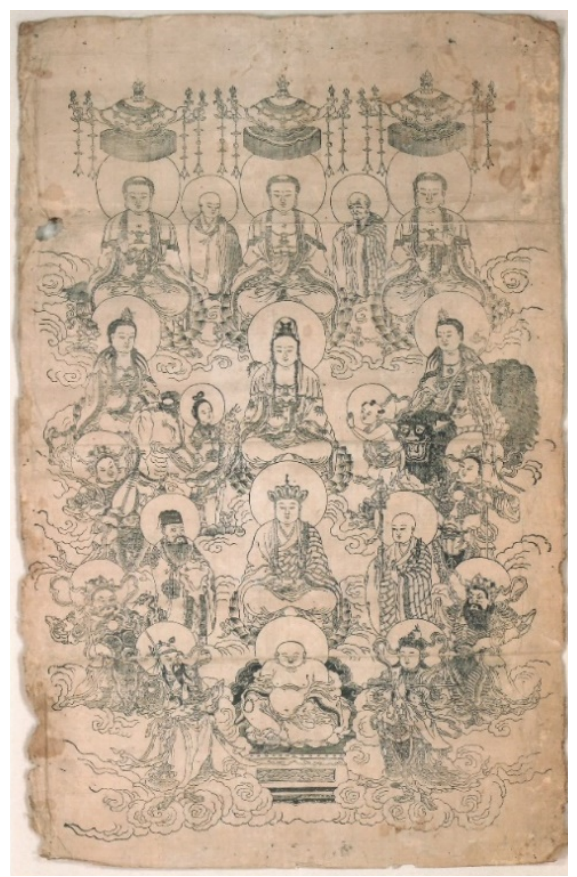

Figure 13. Assembly of Deities. Early 20th century. Print on paper. $69.0 \times 44.0 \mathrm{~cm}$. Puyongsa, Kimje, North Chŏlla Province. After (Kungnip Kongju Pangmulgwan 2012, p. 148).

Further back is another pond with souls of the reborn making offerings to Amitābha Buddha surrounded by bodhisattvas and disciples (Figure 14). Seated inside the twostoried palatial architecture on the uppermost part is a Buddha with his right hand touching the earth and left hand in his lap (Figure 15). Although these two mūdras are usually associated with Śākyamuni Buddha, the identity of this Buddha remains somewhat inconclusive due to the ambiguity caused by signboards hung on the first and second stories. "Hall of Immeasurable Light" (Muryangsujŏn 無量壽殿), written on the signboard on the first story, 
indicates that the hall is dedicated to Amitābha Buddha. By contrast, the signboard on the second story, reading “Hall of Light" (Kwangmyŏngjŏn 光明殿), seemingly identifies the master of the hall as Vairocana Buddha. ${ }^{37}$

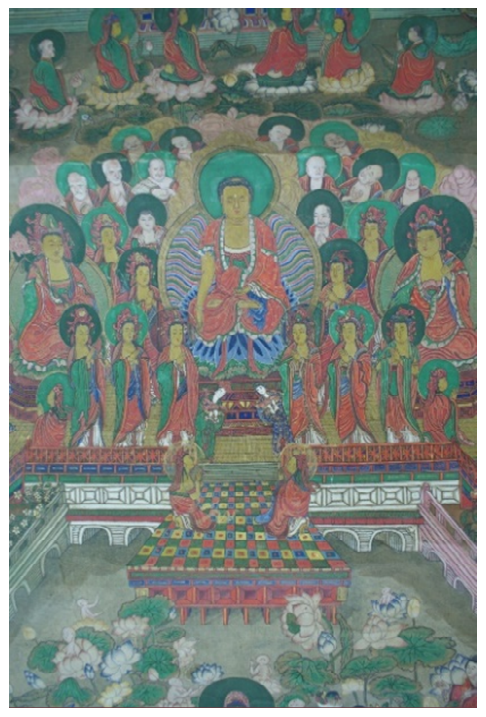

Figure 14. Detail of Three Gates in a Single Mind showing Amitābha Buddha in the central frame. Photograph by Choi Yeub.

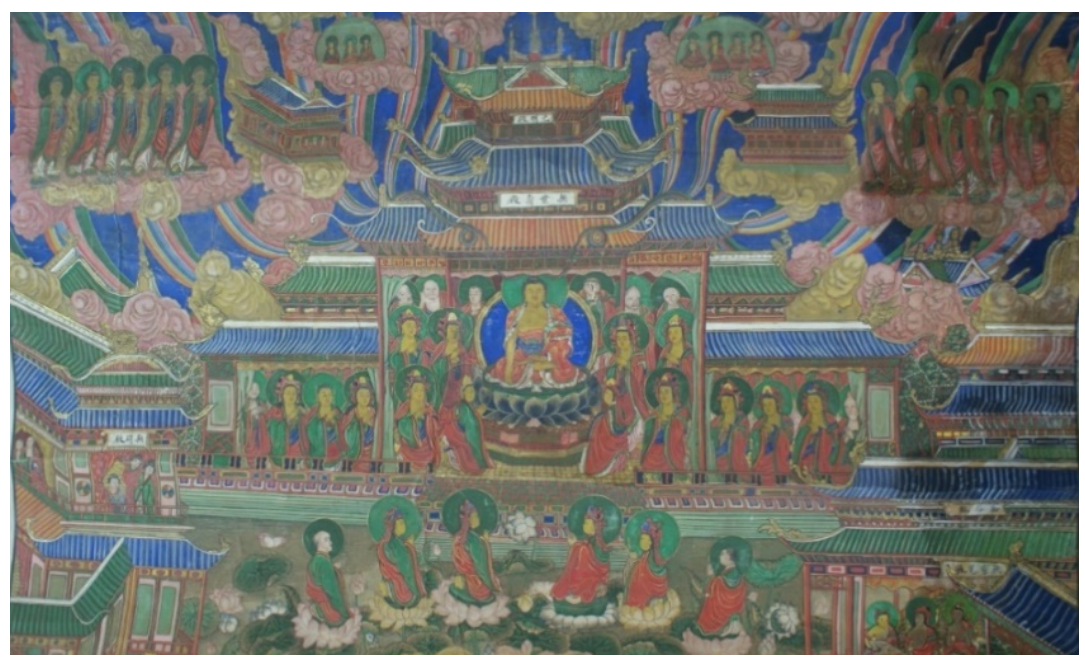

Figure 15. Detail of Three Gates in a Single Mind showing Buddha's assembly in the central frame. Photograph by Choi Yeub.

The left frame is also shown emanating from the white circle in the central section. It largely divides into two sections as well. Along the bottom are the raging waves from which Mount Sumeru, the center of the Buddhist universe, rises. On the left and right, the mountain is flanked by the sun and moon, respectively. A young man carries his parents across a mountainside, an iconographic motif alluding to a passage in the Sütra on Deep Indebtedness to Ones Father and Mother (Pumo ŭnjung kyŏng 父母恩重經) (Figure 16). Specifically, the passage states that repaying one's parents for their kindness is impossible, even if one were to carry them around Mount Sumeru until one's bones wore down. The frame bears close affinity to the twelfth scene, called "Going around Mount Sumeru" (Chuyo Sumi 周須彌), and the fourteenth, called "Making one's parents ascend to the heavenly realms and enjoy pleasure" (Sanggye k'waerak 上界快樂), in the Chinese and venarcular Korean editions of Sütra on Deep Indebtedness to Ones Father and Mother published under 
the royal patronage at Yongjusa 龍珠寺 in 1796 (Ch'oe 2005, pp. 181-82; Kang 2010, pp. 176-79) (Figures 17 and 18). ${ }^{38}$

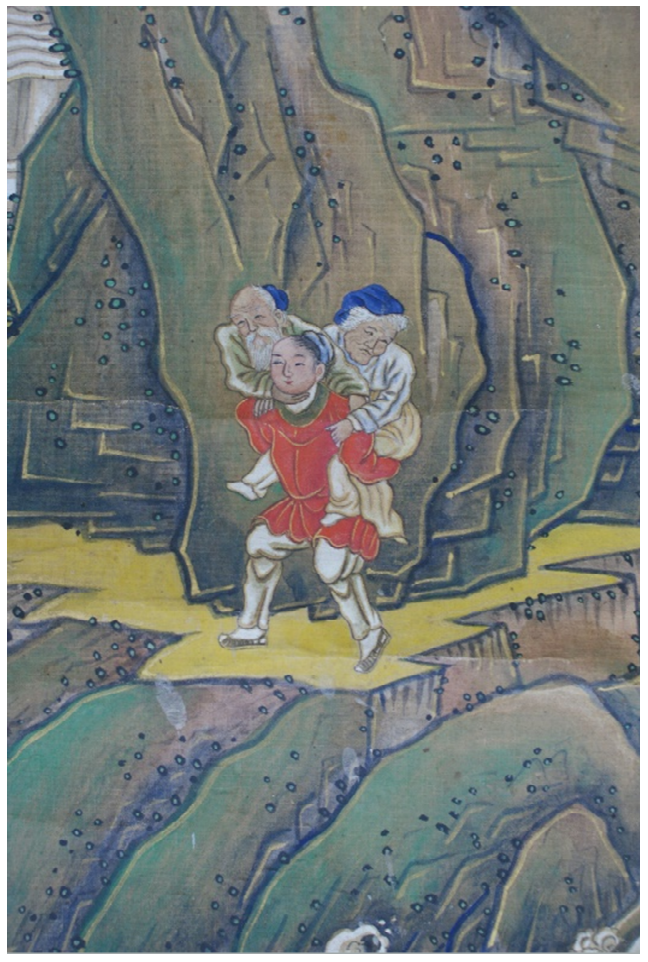

Figure 16. Detail of Three Gates in a Single Mind showing the scene of going around Mount Sumeru in the left frame. Photograph by Choi Yeub.

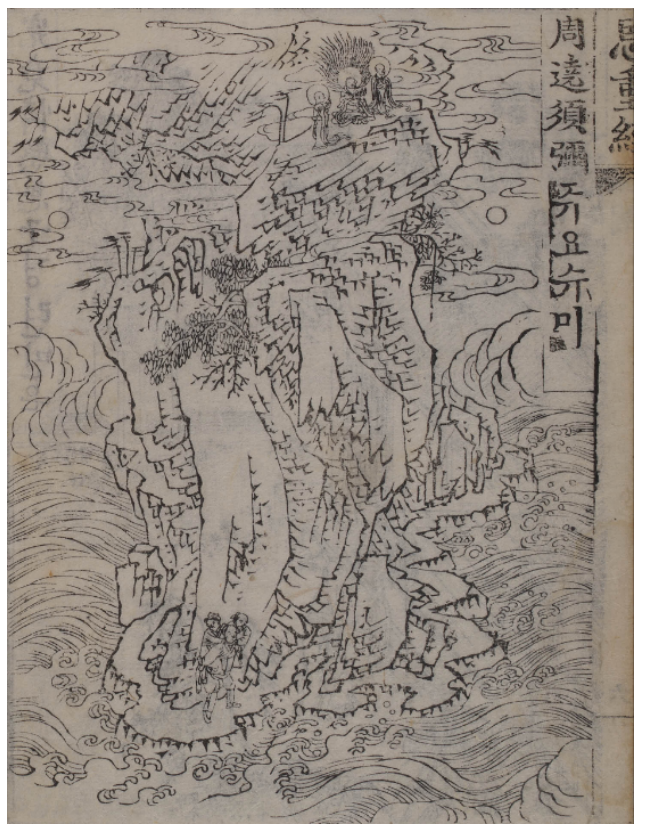

Figure 17. "Going around Mount Sumeru" from the vernacular Korean edition of Sütra on Deep Indebtedness to Ones Father and Mother. Chosŏn, 1796. Woodblock printed on paper. $22.0 \times 16.0 \mathrm{~cm}$. Courtesy of Dongguk University Library. 


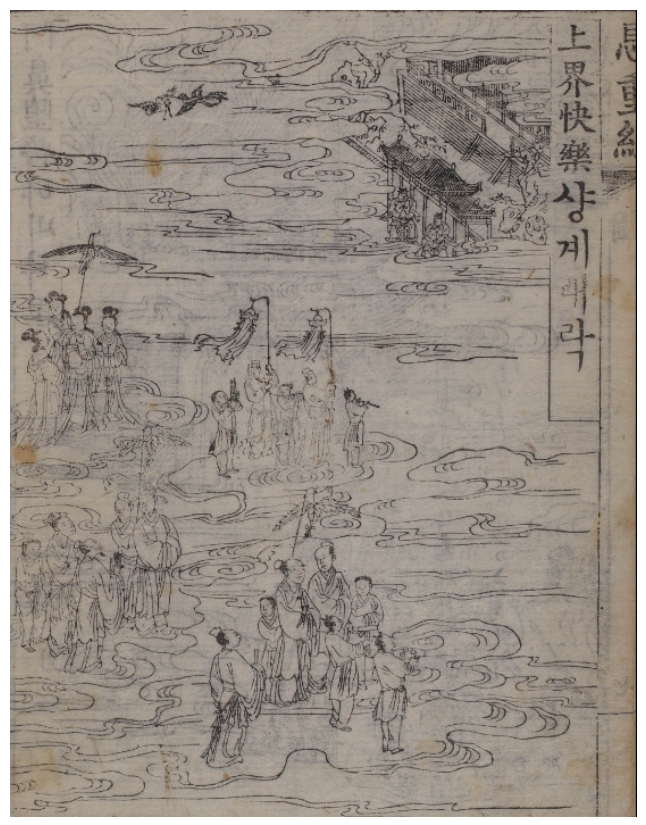

Figure 18. "Making one's parents ascend to the heavenly realms and enjoy pleasure" from the vernacular Korean edition of the Sütra on Deep Indebtedness to Ones Father and Mother. Chosŏn, 1796. Woodblock printed on paper. $22.0 \times 16.0 \mathrm{~cm}$. Courtesy of Dongguk University Library.

Illustrations inserted in the Yongjusa edition of the sūtra are said to have been composed by the prominent court painter Kim Hongdo 金弘道 (b. 1745). Comparative analysis of the illustrations has revealed affinities to Kim Hongdo's paintings and court paintings of the eighteenth century (Pak 2006). Ch'ukyŏn was well aware of Kim Hongdo's oeuvre, as exemplified by his replication of the Album of Genre Paintings in the British Museum. Several leaves of the British Museum's album bear the impression of a seal reading "Mun Hyesan chang" 文蕙山章 (Chin 1999, p. 393; Shin 2014, pp. 126-29). Hyesan was a dharma sobriquet that Ch'ukyŏn used primarily in his early career before returning to lay life in the late 1890s. Given that Ch'ukyŏn produced Guardian Deities (Sinjung to 神衆圖) for Yongjusa in 1913, he may have possessed firsthand knowledge of the printing blocks or imprints of the sūtra in the temple collection. ${ }^{39}$

The upper part portrays those who are heading to the heavenly palace as a result of their children's dedication of the sūtra (Figure 19). Scattering flowers from their baskets, two heavenly maidens are welcoming the righteous souls to the heavenly palace, represented by a hexagonal building. Given the theme of filial responsibility governing the lower half of the frame, the building seems to have represented the Palace of Tusita Heaven (Tosolch'ŏn kung 舀率天宮), although it is not identified with a signboard. Tusita Heaven, the fourth of the six heavens in the desire realm, is where Śākyamuni Buddha dwelled before his birth in the physical world and where his late mother Queen Mãyā is said to have been reborn. It is also the Pure Land where Maitreya Bodhisattva is said to have waited until his descent to earth. The Buddha, seated on a blue lotus throne upon a hexagonal pedestal, touches the earth with his right hand while raising his left before his chest (Figure 20). He is surrounded by men and women wearing distinctive headgear, monks, bodhisattvas, and heavenly maidens. The identity of this Buddha remains ambiguous, like the Buddha depicted in the uppermost part of the central frame, due to the rather unorthodox iconography. Behind the hexagonal pavilion are oddly shaped rocks and trees full of heavenly peaches against an azure sky. The peaches recall those depicted in folk paintings from the late Chosŏn (Kang 2010, p. 180). The azure sky is filled with musical instruments that are playing of their own accord. Ch'ukyŏn appears to have borrowed these motifs from the decorative paintings that were wildly popular among residents of the capital from the late Chosŏn onward. ${ }^{40}$ 


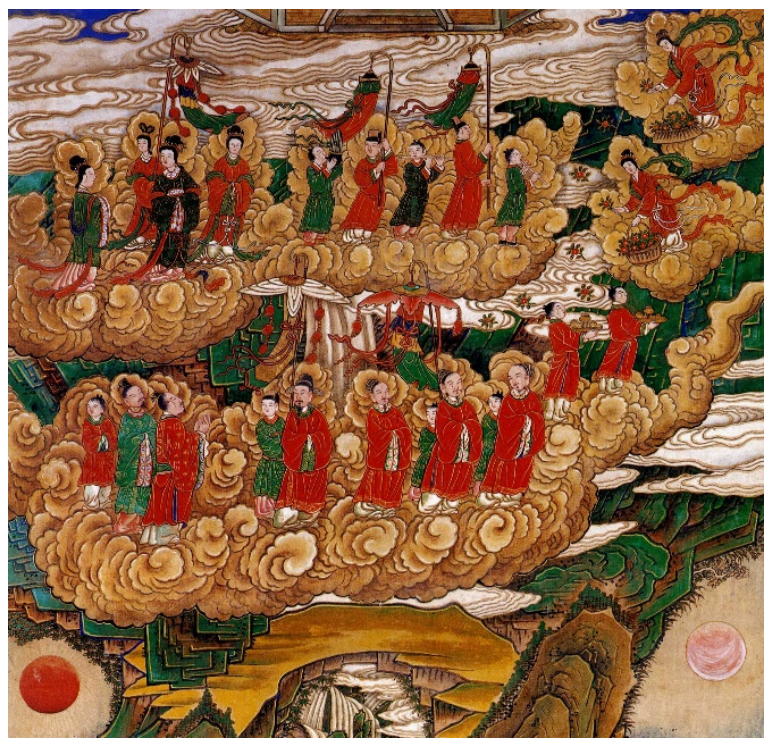

Figure 19. Detail of Three Gates in a Single Mind showing the scene of good men and women's ascent to the heavenly palaces in the left frame. After (Sŏngbo Munhwajae Yŏn'guwŏn 1997, p. 186).

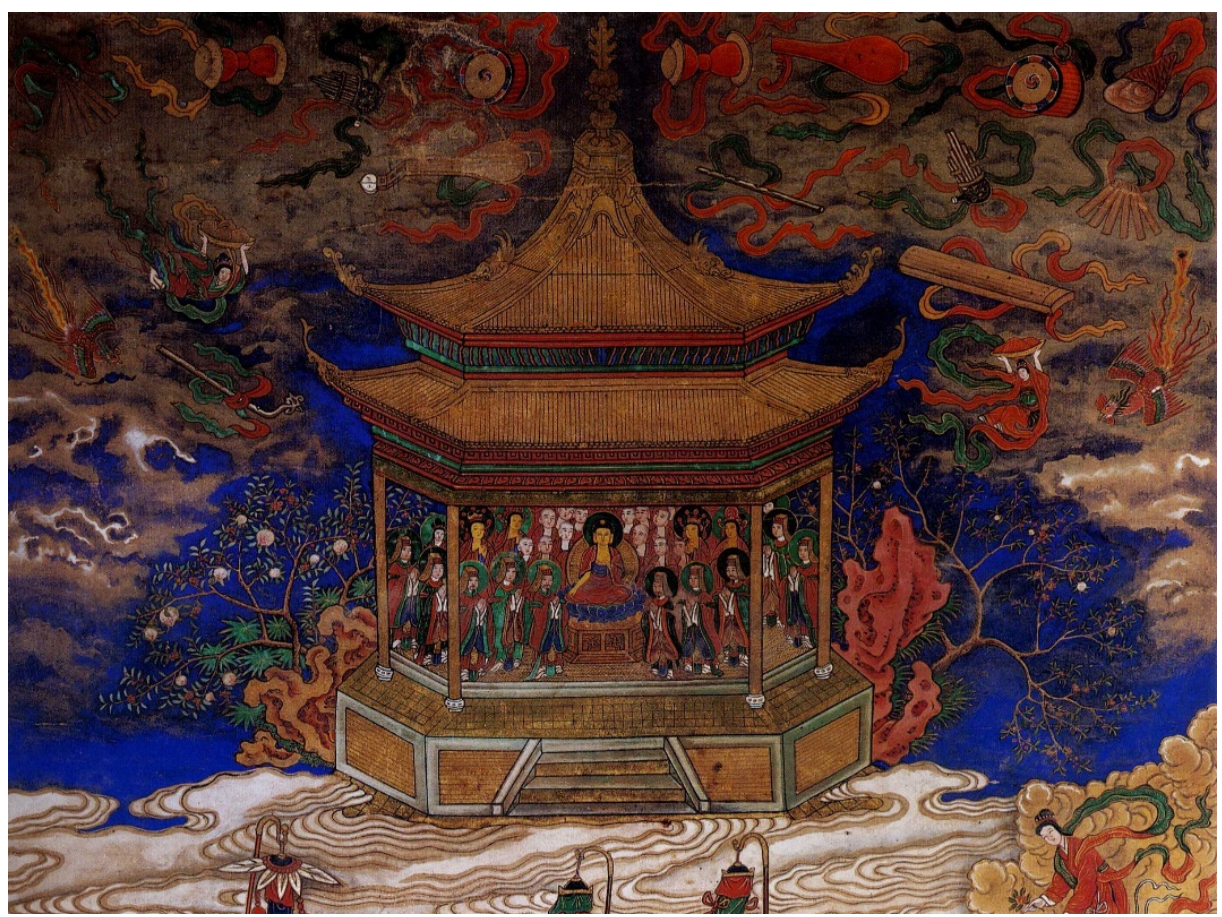

Figure 20. Detail of Three Gates in a Single Mind showing the Palace of Tusita Heaven in the left frame. After (Sŏngbo Munhwajae Yŏn'guwŏn 1997, p. 185).

The painting as a whole, from the manner of writing in the inscription to the overall composition, to the combination of iconography, has no precedent in the history of Korean Buddhist painting. The novel composition, as Choi Yeub has noted, must have been borne of a strong will to create a painting specifically for the preaching hall of an urban propagation space at the center of Seoul (Ch'oe 2014a, p. 208). The right frame appears to have been depicted emanating from the white circle. What might have been depicted at the end of the dark ray? Some suggest that the right frame may have illustrated both good and bad deeds as well as the hell reserved for sinners in the afterlife (Sŏkjŏng 1997, p. 228). Others suggest that the right frame would have depicted scenes of hell in opposition to 
scenes on the left (Ch'oe 2012b, pp. 288-89; 2014a, p. 207; Kang 2015, p. 365). As we have examined above, the surviving two frames illustrate different means for ascending to the Western Paradise. Given the symmetrical composition of the painting as a whole, the right frame may have represented yet another means of ascending to the Pure Land.

\section{Propagating Buddhism in New and Old Styles}

The founding of an urban Buddhist temple on the former site of Sŏnwŏnjŏn was a great success in the decades-long effort to restore Buddhism to Seoul. Surely, the dedication of Three Gates in a Single Mind was part and parcel of the propagation enterprise. The painting differs not only from late Chosŏn Buddhist paintings but also from contemporaneous Korean Buddhist paintings produced specifically for propagation halls. More than 80 Buddhist paintings are recorded to have been produced for urban propagation temples, variously called $p^{\prime}$ ogyoso, p'ogyodang, or kyodang 教堂 in their dedicatory inscriptions (Ch'oe 2014a, p. 206n14). This number is culled from a collection of approximately 3,200 votive inscriptions remaining on extant Korean Buddhist paintings produced up until 1950 (Kogyŏng et al. 2011). ${ }^{41}$ Generally speaking, the subject matter of these paintings does not deviate from the tradition of late Chosŏn Buddhist paintings, such as buddhas and bodhisattvas, guardian deities, seven stars (ch'ilsŏng 七星), and minor gods, such as the mountain god (sansin 山神), hermit sage (toksŏng 獨聖), and King Yama (Hyŏnwang 現王). In comparison, Three Gates in a Single Mind is unprecedented in conception, idiosyncratic in iconography, and innovative in painterly technique. Ch'ukyŏn created a novel composition that none of his contemporaries had seen before.

Yet, this modern Buddhist painting is still replete with old motifs, such as the dragon boat of wisdom, that immediately recall the lay salvationism of the previous century. In other words, makers of the new Buddhist painting were aware of the affective power of the age-old motif and made the best use of it rather than eschewing it. This iconographic choice in turn raises the question of viewership. Who, then, were its intended viewers? Or, who constituted the congregation of this urban propagation space? Further questions arise: what type of Buddhist ideas and practices did Yi Hoegwang and like-minded monks propagate in this establishment? Or, what type of initiatives did they implement to facilitate city dwellers' conversion to Buddhism in an environment of such competition amongst religions? As the modern transformation of Korean Buddhism presented new challenges, what roles did religious icons and traditional cultic practices play in an urban Buddhist temple? To answer these questions, we must first examine Yi Hoegwang's vision of propagation, which was borne out of Korean Buddhism at the start of the twentieth century, and the nature of congregation at the propagation space.

Many of the reform-minded Buddhist leaders concurred that Korean Buddhism had gone to the two extremes of the clergy-centered tradition of Sŏn Buddhism, practiced in temples in the deep mountains, and lay Buddhism, which was often associated with ritual practices geared toward achieving secular desires that ranged from attaining better rebirth to enjoying good health and longevity to obtaining a son. The gulf between the ideal of monasticism and the reality of lay Buddhism seemed unbridgeable to some reformers such as Han Yong'un, inarguably the most vocal opponent to the attempt to synthesize the Wŏnjong and the Sōtōshū in 1910 (Hur 2010, p. 89). For instance, Han Yong'un called for an end to old practices of Korean Buddhism, including elitist institutional Buddhism and lay salvationism. Critical of lay-driven, or vulgar, Buddhist practices, Han Yong'un even argued for the demolition of yŏmbultang 念佛堂 (lit. "Chanting Hall”), the focus of verbal chanting of Amitābha Buddha's name, as well as the removal of all divine images except for that of the Buddha, to restore what he regarded as the essence of Buddhism (Han 1913, pp. 27-31, 43-53). ${ }^{42}$ The recitation of which Han Yong'un was so critical corresponds to the Ten-Thousand-Day Buddha Recitation Assembly (Manil yŏmbulhoe 萬一念佛會) that had gained wide popularity across social groups from the late nineteenth century onward (Cho 2003, pp. 103-8; Lee 2019, p. 38). The Buddhist community of monastics and lay followers was devoted to the ritualized recitation of Amitābha Buddha's name 
for ten thousand days, which amounts to more than twenty-seven years, in aspirations for rebirth in the Western Paradise. Typically, members of the Ten-Thousand-Day Buddha Recitation Assembly chanted Buddha's name loudly to the pounding of a drum and gong. Like Han Yong'un, some monks criticized the noisy and even agitating character of the Buddha-recitation practice (S. Kim 2019, pp. 260-64). Without a doubt, Pure Land zeal was one of the key drivers of Buddhist art and architecture in the late nineteenth century. ${ }^{43}$ Halls dedicated to such lay-driven practice, usually called Yŏmbultang or Taebang 大房 (lit. "Large Chamber"), were erected across the peninsula, ${ }^{44}$ and Buddhist paintings with Pure Land themes were produced for such halls under the auspices of members of these Buddhist communities. ${ }^{45}$

Despite disputes over political issues, Korean Buddhist leaders perceived propagation as a vehicle for revitalizing their religion (Nathan 2018, pp. 55-60). Many suggested multiple forms of propagation, such as publishing newspapers and journals, translating and widely circulating Buddhist sūtras, and implementing educational and social welfare programs in their reform proposals, which appeared in print in the 1910s and 1920s. It is notable that Yi Hoegwang carried out almost all of the propagation methods put forward in contemporaneous reform proposals, first at Wŏnhŭngsa and later at Haeinsa, although many of his works came to a halt due to the turbulence of the times. For instance, he served as principal of the first modern educational institute for monks, Myŏngjin School 明進學 校, from 1908 to 1910, published the first modern Buddhist journal in 1910, and played a seminal role in the establishment of Kakhwangsa in 1910 (Taehan Pulgyo Chogyejong 1998, pp. 116-17; Kim 2012, p. 233).

Yi Hoegwang strove to find a middle ground in bringing Buddhism closer to society, while serving the populace and simultaneously making best use of lay support. With the founding of the Buddhist Central Propagation Space, he was better equipped to carry out various outreach programs for propagation, although his abbotship only lasted from 1920 to $1924 .{ }^{46}$ His vision can be glimpsed in a piece of writing published in the magazine Chosen 朝鮮 one month after the successful celebration of the Buddha's birthday, during which Three Gates in a Single Mind was dedicated. Yi Hoegwang revealed his strong ambitions to galvanize Korean Buddhist monks and work for the public good. After narrating the glorious past of Korean Buddhism in the Silla 新羅 and Koryŏ periods, he faulted the Chosŏn government for the eventual decline of Buddhism while crediting the colonial government for promulgating the Temple Ordinance of 1911, under which Korean Buddhist temples were vitalized and the rights of six thousand Korean Buddhist monastics were recovered. He further claimed that Korean Buddhist monks, who had been isolated in the remote mountains, needed to fundamentally reform themselves. In Yi Hoegwang's opinion, Buddhism needed to be transplanted from the remote mountains to function as a social religion and no longer the preserve of monastics. Korean Buddhist leaders, he claimed, should engage in modernizing enterprises of social welfare that contribute to the state and society. As for specific solutions, he suggested the establishment of clinics, educational institutions (kyoyuk changnyŏwŏn 教育獎厲院), facilities for rehabilitation and public hygiene, such as free accommodations, employment agencies, public baths, and laundries, and correctional centers for tenants (sojagin kyohwawŏn 小作人教化院) (Yi 1921, pp. 61-65). ${ }^{47}$ Herein, Yi Hoegwang not only repeated colonizers' claims of the Chosŏn's failure to continue the glorious legacy of Korean Buddhism but also resonated with his contemporary Buddhist reformers, some of whom were his political opponents, revealing the complex realities of colonial Buddhism.

In practice, the Buddhist Central Propagation Space harmonized the "old and new methods" of propagation to win lay adherents. ${ }^{48}$ It implemented a variety of modern outreach programs - from public lectures to larger-scale ones such as education of women, medical social work, and charity - in order to increase its social presence and participation. For instance, the urban Buddhist establishment opened its doors to lay organizations so that they could hold regular meetings and open forums on social issues. ${ }^{49}$ It hosted public lectures organized by the Great Meeting of Korean Buddhism (Chōsen Bukkyō 
Taikai 朝鮮佛教大會), the lay Buddhist movement of pro-Japanese orientation established in 1920 under the pretense of building bridges between Japanese and Korean Buddhist communities, on several occasions. ${ }^{50}$ Speakers included elite Korean monks such as Yi Hoegwang himself, Paek Ch'owŏl 白初月 (1878-1944), and Kim Yŏngsu 金映逐 (18841967), influential Japanese missionaries such as Gotō Tangan, with whom Yi Hoegwang attempted a merger of Korean Buddhism in early 1920, and Henmi Tsūkan 逸見通漢 of the Japanese Nichirenshū 日蓮宗, and prominent Korean and Japanese lay Buddhists such as Yi Wŏnsok 李元錫, a key member of the Great Meeting of Korean Buddhism. ${ }^{51}$ The women's Buddhist association (puinhoe 婦人會) of the propagation space also held a lecture meeting where female lay Buddhists gave public talks. ${ }^{52}$ In July 1921, the Buddhist Central Propagation Space founded the Kyŏngŏsong Women's Culture School 京城女子文化學 院 to provide women post-secondary education on the arts, philosophy, and language. ${ }^{53}$ Two years later, the Pulgyo Chejungwŏn 佛教濟衆院, the first modern Buddhist medical clinic, was founded by Yi Hoegwang and his partner Chang Il 張——who turned out to be a fraud-within the precinct of the Buddhist Central Propagation Space for the welfare of society, despite financial difficulties caused by embezzlement in $1922 .{ }^{54}$ The Buddhist clinic intended to provide medical care for general patients at actual cost. ${ }^{55}$

Apart from these modern programs, Yi Hoegwang adhered to dual practices of Sŏn and Kyo that had been the pillars of elitist monastic Buddhist tradition. He attempted to bring the orthodox practice of elitist Korean Buddhism to the heart of the capital. From the beginning, he established a meditation room within the precinct of the urban temple and invited an eminent Sŏn master from Haeinsa (Koam 1990, p. 375). In May 1922, the propagation space invited ten dharma masters renowned for their erudition and virtue to study Buddhist doctrines for two months. The dharma masters would have led the recitation of sūtras (chŏndok 轉讀) 一the practice of scanning scriptures by reading the beginning, middle, and end of each chapter-in the morning and given dharma talks in the traditional style ( $k$ u chedo sŏlpŏp 舊制度說法) in the afternoon. ${ }^{56}$ This was followed by seated meditation in the evening. The propagation space also planned to invite distinguished guests to give public talks on Sundays. ${ }^{57}$

The foregoing analysis reveals the astounding feat of Yi Hoegwang and his propagation space in the early 1920s. Haeinsa and lay Buddhist followers, particularly court ladies and women of high social standing, were the two pillars that buttressed his cause financially. On the one hand, Yi Hoegwang - as abbot of one of the most prestigious head temples-possessed the power to manage the properties of Haeinsa and its branch temples, and made use of these properties within the framework of the Temple Ordinance. On the other hand, he received lavish patronage from laywomen who were traditionally ardent supporters of Buddhism. A snapshot of Yi Hoegwang's laywomen followers can be glimpsed in a newspaper article published in the wake of his attempt to merge Korean Buddhism with the Myōshinji lineage of the Linzaish $\overline{.} .^{58}$ Other sources also indicate that laywomen Buddhists were the main benefactors of propagation halls in Seoul in the early twentieth century (Hyedam 2002, p. 24). Ownership of the Sŏwŏnjŏn area, which had been divided from the Tŏksugung in March 1920, was transferred to Ch'angdŏkkung-where Sungjong 純宗 (1874-1926, r. 1907-1910) resided-until 1931 (Chang and Chŏn 2013, p. 203). Yi Hoegwang was reported to have arranged installment payments to the Office of Yi Royal Household that managed properties of the former royal house. In retrospect, he could purchase the property by taking out a loan against the land owned by Haeinsa. ${ }^{59}$ However, this alone does not suffice to explain how he got hold of this land that so many Japanese entrepreneurs coveted.

Ch'ŏn Ilch'ŏng 千一清 (also known by her dharma name Chŏnggongsim 淨空心, b. 1846), who served the last ruler of the short-lived Great Han Empire at Ch'angdŏkkung as one of the highest-ranking court ladies, seems to have worked as the crucial intermediary between Yi Hoegwang and the colonial government (Figure 21). Lady Ch'ŏn, brought into the court at the age of four, possessed wealth and power thanks to her close connections to Chosŏn's royal court (Kim 1987, pp. 20, 59, 400-1). Like members of the royal family and 
other court ladies of the late Chosŏn, she had been a devout Buddhist from a very young age to the extent of being described in a newspaper as a "model Buddhist believer." ${ }^{60}$ When Noble Consort née Ŏm (posthumously entitled Sunhŏn hwanggwibi 純獻皇貴妃 嚴氏， 1854-1911) was alive, she served as a go-between to find temples that could dedicate prayers for the royal family. On behalf of her queen, Lady Ch'ŏn oftentimes went outside the four gates of Seoul to meet monks and offer financial resources in exchange for prayer services and temple repairs (Kim 2012, p. 251) ${ }^{61}$ When Yi Hoegwang came to Seoul in early 1907 , she is said to have heard rumors that a great master was in town. She then invited him and had him stay at her residence whenever he visited Seoul thereafter (Hyedam 2002, pp. 119-20). ${ }^{62}$ As a devout Buddhist, she patronized the production of Buddhist paintings on her own accord with other court ladies even before she met Yi Hoegwang. ${ }^{63}$ In 1908 she donated a large sum of resources for the construction of Kunghyŏngdang 窮玄堂, where monks would engage in doctrinal study, as well as the renovation of Kwanŭmjŏn 觀音殿 into Simgŏmdang, a building for monks' residence, at Haeinsa for which Yi Hoegwang exhorted believers to give alms. ${ }^{64}$ He supervised the whole process. ${ }^{65}$ A stone stele, erected at Haeinsa in 1919, further attests to her unfailing support of Yi Hoegwang over the years. ${ }^{66}$

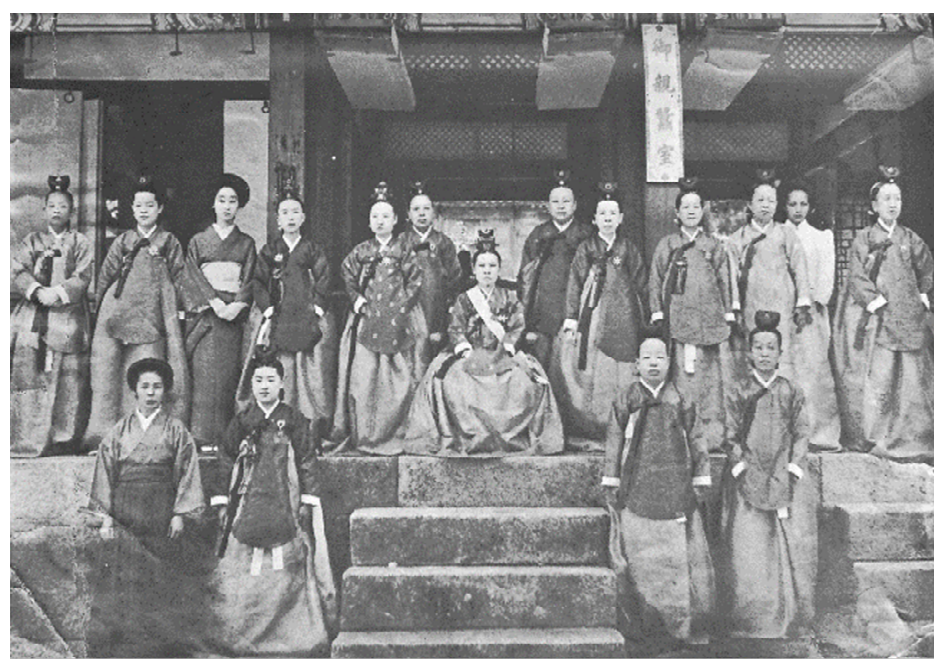

Figure 21. Queen (center) and court ladies, including Ch'ŏn Ilch'ŏng to her right, on the day of the Queen's sericultural ceremony at Sŏhyanggak of Ch'angdŏkkung. After (Kim 1987, n.p.).

More importantly, she contributed to efforts to modernize Korean Buddhism during the pre-colonial and colonial eras. Drawing on a wide network of relationships both inside and outside the court, Lady Ch'ŏn helped Yi Hoegwang to establish the Wŏnjong and received a donation of the property from the royal house when Kakhwangsa was founded (Kim 2012, pp. 251-52; Kang and Pak 2002, p. 46). Furthermore, she gave alms to victims of natural disasters and made several generous contributions for the cause of women's education. ${ }^{67}$ In a piece of writing submitted to the Buddhist journal Chosŏn Pulgyo wŏlbo 朝 鮮佛教月報, she urged laywomen to abandon the degenerate practices of the old days and to engage in charity work (Ch'ŏn 1911, pp. 44-47). Given their continued collaboration in the 1910s and 1920s, it is highly plausible that Lady Ch'ŏn helped Yi Hoegwang pull strings in the Office of Yi Royal Household. She continuously supported him by donating large sums for the founding of the Pulygo Chejungwŏn. ${ }^{68}$

It is noteworthy that Lady $\mathrm{Ch}^{\prime}$ ŏn and other prominent lay women Buddhists were practitioners and patrons of Pure Land Buddhism. As examined previously, Three Gates in a Single Mind was commissioned for the Sŏlpŏpchŏn of the propagation space where weekly dharma talks and special guest lectures would have been held (Figure 8). The painting must have looked modern to the congregation with its painterly technique and bold composition that had never been attempted before in Korean Buddhist paintings. At the same time, it was decipherable enough for laywomen Buddhists like Lady Ch'ŏn, who 
had been a member of the Ten-Thousand-Day Buddha Recitation Assembly formed in 1891 at Pogwangsa, a temple that received lavish patronage from members of the royal family and court ladies. ${ }^{69}$ There were few such assemblies in the capital area until the very end of the nineteenth century, due to restrictive measures against Buddhist monks. Yet, urban lay Buddhists were able to participate in this cultic practice at temples closer to home from the beginning of the twentieth century. In the early 1910s, three temples located in the capital area-Hwagyesa 華溪寺, Pongwŏnsa 奉元寺, and Kaeunsa 開運寺一launched the Ten-Thousand-Day Buddha Recitation Assembly. Given the chief location of the Buddhist Central Propagation Space and Yi Hoegwang's adherence to the Sŏn and Kyo, both in terms of practices and appellation in the traditional manner, it seems unlikely that the propagation space formed such an assembly or encouraged loud chanting of the name of Amitābha Buddha. However, aspirations for the Pure Land were the perennial motive driving lay Buddhists to patronize Buddhist temples and to engage in a variety of social works, as in the case of Lady Ch'ŏn. As a way to fulfill the religious aspirations of many lay adherents, Yi Hoegwang seems to have commissioned Three Minds in a Single Gate, which illustrates the promise of salvation for the devout, instead of building a hall for Pure Land practices or forming the Ten-Thousand-Day Buddha Recitation Assembly.

\section{Conclusions}

The establishment of the Buddhist Central Propagation Space in 1920, examined thoroughly for the first time in this study, shows a meaningful yet ultimately unsuccessful attempt at modernizing Korean Buddhism in the dynamics of the colonial Buddhism. Although the propagation space is significant in the history of Buddhist propagation and respatialization of Seoul during the early colonial period, it has not received the attention it deserves, due to the pro-colonialist undertakings of its founder, who has been severely criticized in later historiography. The propagation space, as my analysis has revealed, was a byproduct of Yi Hoegwang's incessant attempts to achieve governmentality for Korean Buddhism, even if it meant collusion with the colonizer. I have also discussed the seminal contribution of Lady Ch'on to the founding of the propagation space, thereby restoring the voice of one important laywoman in the modernization of Korean Buddhism. Enshrining a gilt Buddha statue in place of the portraits of rulers of the bygone dynasty seemingly attests to the success of Yi Hoegwang, who had long strived to reinstate Buddhism in the center of state and society. In this sense, the founding of the Buddhist Central Propagation Space was surely a glorious moment for those who sought to modernize Korean Buddhism in their own way. However, the moment was far from long-lasting. The properties of the propagation space, except for a Buddha statue, were seized since Yi Hoegwang could not even pay loan interest. ${ }^{70}$ In 1924, Yi Hoegwang eventually lost his abbotship of Haeinsa and its branch in Seoul due to the huge financial scandal. ${ }^{71}$ Lady Ch'ŏn also suffered from disgrace and financial difficulties in the last days of her life. ${ }^{72}$ Although the propagation space lasted until the early 1930s, it appears not to have regained the fame and social presence it had enjoyed in the early 1920 s. $^{73}$

Shifting the focus from nationalistic critique of Yi Hoegwang's pro-Japanese endeavors to his propagating efforts, I have illuminated the role of this propagation space in restoring the ritual and material culture of Korean Buddhism-denounced by some contemporary Buddhist reformers - to the heart of the colonized capital. In so doing, this study has broadened the horizons of previous studies on the governmentality and propagation of Korean Buddhism in the early colonial period. In practice, the propagation space harmonized the new and old methods of propagation to win lay adherents, while attracting women of high social standing who had been fervent supporters of Korean Buddhist temples in times of hardship under the Chosŏn rule. My discussion of Three Gates in a Single Mind, produced for the Sŏlpŏpchŏn of the propagation space on the Buddha's birthday in 1921, further illuminates the complex dynamics among leading Korean monastics like Yi Hoegwang, famous monk painters such as Ch'ukyŏn, and lay Buddhist women in the early colonial period. Three Gates in a Single Mind must have been appealing to temple-goers of 
the time, due to its dramatic presentation of visual wonders. Deviation from the norms of late Chosŏn Buddhist paintings may have been understood in the contemporary movement of bringing Buddhism closer to the masses in the early colonial period. In this sense, the genre of Buddhist paintings communicated more with society and the public, reflecting the social conditions of the day.

Three Gates in a Single Mind stands out for its unique iconography and bold composition even among contemporaneous Buddhist paintings similarly produced for propagation halls. The visual wonder is largely achieved by Ch'ukyŏn's deft employment of pictorial idioms borrowed from both secular and Buddhist traditions. Ch'ukyŏn made apt use of motifs derived from contemporaneous folk paintings in the depiction of heavenly palaces and beautiful flowers and plants, while also incorporating the motifs of the salvific dragon boat and the nine grades of rebirth in the Western Paradise from the recent past. The salvific dragon boat, featured so prominently in the central frame, was surely one of the motifs that could arouse lay interest in Buddhism for its overt salvationism. Although the motif was not frequently painted in the colonial period, it seems to have been considered important by Ch'ukyŏn perhaps due to its affective power. The combination of the dragon boat and the nine grades of rebirth, with which Ch'ukyŏn had experimented in the pair of paintings at Anyang'am, may have fulfilled lay Buddhist followers' strong aspirations for the Pure Land. Hung inside the Sŏlpŏpchŏn of the Buddhist Central Propagation Space, the painting must have served as an icon to which modernizing elites of Korean Buddhism as well as lay Buddhist adherents paid respect before dharma talks, public lectures, and other activities. As such, the painting not only attests to the vitality of the Pure Land zeal but also the new meaning ascribed to the much denounced desires of lay patrons. As I have demonstrated above, Three Gates in a Single Mind was designed to convey moral lessons to Buddhist devotees as well as encourage them to do good. This practice, new to Buddhist altarpieces, was designed for this new type of religious space where the public could reformulate themselves spiritually and learn the true spirit of Buddhism.

Funding: This research received no external funding.

Acknowledgments: Parts of this study were first presented at the panel "Empathy Seen in Korean Visual Art in a Time of Crisis" at the annual conference of the Association of Asian Studies in March 2021. I am grateful to Todd A. Henry, who served on the panel, and participants at the conference for their thoughtful comments on my presentation. My special thanks goes to Choi Yeub (Ch'oe Yŏp) for granting me permission to use her photographs and sharing her deep knowledge of modern Korean Buddhist paintings and to Lee Jongsu for sharing his expertise on late Chosŏn Buddhism. I would like to also thank my two anonymous reviewers for their constructive feedback on an earlier version of this essay. Needless to say, any errors that may remain are my own.

Conflicts of Interest: The author declares no conflict of interest.

\section{Notes}

1 The rescinding of this infamous law has been widely portrayed as the starting point of modern Korean Buddhism, see (Sŏ 1973, p. 41; 2006, p. 59; Kim 1998, p. 33). For more on this event and its historical implications, see (Kim 2012, pp. 123-28).

2 The religious topography of 1920s Seoul is outlined in (Kim 1924). The notion of competition for lay followers was shared by many Korean Buddhist reformers in the early colonial period. See (Nathan 2018, pp. 56-57).

3 By 1926, Christianity had expanded rapidly on the peninsula with a Korean congregation of more than 340,000, whereas Korean Buddhist temples had a native congregation of 210,000. See (Chōsen shyūkyōkai genjyō 1926). The article divides the number of followers into the three categories of Japanese settlers, Koreans, and foreigners, although it does not identify the source of these numbers. By the end of the Japanese colonial period in 1945, there were more than 400 Korean propagation establishments, the majority of which had been founded after the mid-1920s. See (H. Kim 2018, p. 234).

4 For relevant cases, see (S. Yi 2004a; U and Pak 2009; An 2009; Henry 2014; Lee 2021).

5 Hoegwang was his dharma sobriquet (pŏpho 法號). His ordination names (pŏmmyŏng 法名) were Sasŏn 師䫢 and Yusŏn 有瓐. 

critique of his pro-Japanese deeds, see (Im 2005, pp. 48-74).

7 The first Korean branch of the Higashi Honganji was established in Pusan in 1877. See (Kim 2012, pp. 109-18).

8 Tong'a ilbo 東亞日報, 3 July 1920. See also (H. Kim 2018, pp. 189-90).

9 The contents of the compact were reported in Maeil sinbo 每日申報, 2 April 1911.

Tong'a ilbo, 24 June 1920. In 1926, Yi Hoegwang made another failed attempt to build the great head temple of Korean Buddhism in Seoul, where Śākyamuni, Emperor Meiji 明治天皇 (r. 1867-1912) and Emperor Kojong 高宗 (r. 1864-1907) would be enshrined together. See Tong'a ilbo, 12 May 1926.

For more on the history of Tŏksugung, see (Kim 2004; An 2009; Tŏksugung Kwalliso 2020).

Visual and textual sources related to the Sŏnwŏnjŏn area are collected in (Munhwajaechŏng 2014b).

The secret deals were first reported in Tongnip sinmun 獨立新聞, 8 January 1920. For the interview of the vice minister to the Office of Prince Yi Household, see Maeil sinbo, 19 January 1920. For more on the development of the events, see (C. Kim 2014b, p. 82; Munhwajaechŏng 2014b, pp. 117-19).

On 22 November 1919, Yun Ch'iho 尹致吴 (1865-1945), a politician and important activist, criticized Min Pyŏngsŏk 閔丙真 (1858-1940) and Yun Tŏkyŏng 尹德榮 (1873-1940), the highest Korean officials of the Office of Prince Yi Household, for selling out the departed emperor's palace and land within the Yŏngsŏngmun to the Japanese in his diary. See (S. Yi 2004b, pp. 178-79).

Maeil sinbo, 17 February 1920; 3 March 1920. See also Tong'a ilbo, 23 April 1920.

Tong'a ilbo, 15 May 1920.

The transfer of royal portraits was covered in Maeil sinbo, 18 February 1920.

Maeil sinbo, 11 May 1920. See also Tong'a ilbo, 15 May 1920; 25 July 1921.

Maeil sinbo, 22 December 1920.

For a reference to the Sambojŏn, see Maeil sinbo, 27 December 1920. A reference to the meditation room is found in (Koam 1990, p. 375). The Sŏlpŏpchŏn is mentioned in a votive inscription that I will examine in the next section. The two stone monuments have survived and now stand on the campus of Kyŏnggi Girls' High School 京畿女子高等學校 in Seoul. See (Samp'ung enjiniŏring kŏnch'uk samuso 2005, pp. 183-84) for the arrangement of buildings in the late 1920s.

Maeil sinbo, 26 December 1920.

Maeil sinbo, 26 December 1920.

Maeil sinbo, 27 December 1920.

Tong'a ilbo, 15 May 1921. For more on the celebrations for the Buddha's birthday during the colonial period, see (P'yŏn 2002, pp. 73-103).

Tong'a ilbo, 25 May 1920.

Maeil sinbo, 5 May 1921.

I would like to thank Lee Jongsu for helping me grasp the meaning of this inscription.

The verifier of Buddhist paintings supervises whether the given works conform to Buddhist scripture and norms, and officiates various rituals that accompany their production. See (Chŏng 2016, p. 272).

See Maeil sinbo, 23 November 1915.

See Maeil sinbo, 8 January 1915; 23 November 1915; 12 July 1916. See also (Ch'oe 2005, p. 167).

For votive inscriptions of the Tonghwasa paintings, see (Kogyŏng et al. 2011, pp. 237, 894). See (Kogyŏng et al. 2011, p. 616) for that of the Sŏnsŏksa painting and (Kogyŏng et al. 2011, pp. 255, 903-5, 1094-95) for those of the Taedunsa paintings. Ch'ukyŏn also worked with Yi Hoemyŏng 李晦明 (1866-1952), a dharma brother of Yi Hoegwang, on the production of Buddhist paintings at Yongjusa 龍珠寺 in 1913 and Chŏndŭngsa 傳登寺 in 1916, both located in Kyŏnggi Province. See (Kogyŏng et al. 2011, p. 765) for a votive inscription of the Yongjusa painting and (Kogyŏng et al. 2011, pp. 448, 767) for those of the Chŏndŭngsa paintings.

For more on iconographic implications of the circle motif, see (Kang 2015).

For reproductions of relevant paintings, see (Pulgyo Chungang Pangmulgwan 2016, pp. 98-99, 160-169). See also (Mun 2019).

For more on this painting, see (Yi 2013, pp. 70-74).

Chŏngsun, who took a tonsure at Haeinsa in 1914, earned the dharma sobriquet of Songp'a 松坡. He was active as a painter from the early 1920s to the late 1940s. See (S. Yi 2005, p. 45).

Two other monk painters, Poŭng Munsŏng 普應文性 (1867-1954) and Kŭmyong Ilsŏp 金容日临 (1900-1975), borrowed iconographic motifs from this print. Munsŏng adopted the two bodhisattvas and their attendants from the print with minor variations in the Amitābha Buddha's Preaching Assembly, dated 1919, originally produced for Nam'am 南庵 of 
Chŏnghyesa 定慧寺 in Ch'ongyang, South Ch'ungch'ŏng Province. The painting is currently housed at Magoksa 麻谷 寺, Kongju, South Ch'ungch'ŏng Province. Ilsŏp replicated the composition as a whole in his Assembly of All Deities from 1929 produced for Hŭngguksa 興國寺 in Yŏsu, South Chŏlla Province. A copy of the Chinese print is housed in the collection of Puyongsa 芙蓉寺, where Ilsŏp resided until 1950. See (Ch'oe 2014b, pp. 65-72). For illustrations of the relevant paintings, see (Kungnip Kongju Pangmulgwan 2012, pp. 144-49).

Taking cues from the mūdras and the signboards of the building, the art historian Kang Soyŏn has suggested that the scene illustrates the theme of the three bodies of buddhas ultimately being one. See (Kang 2010, pp. 171-72).

For more on the topic, see (Chŏn 2016, pp.173-78; Pulgyo Chungang Pangmulgwan 2020, pp. 68-72).

For reproductions of relevant materials in the Yongjusa collection, see (Chŏn 2016, pp. 195-97; Pulgyo Chungang Pangmulgwan 2020, pp. 73-76).

Ch'ukyŏn's iconographical borrowing from folk paintings is discussed in (Ch'oe 2010, pp. 194-96; Chŏng 2020).

The collection is an offshoot of a nationwide survey of 3,156 Korean Buddhist paintings undertaken by the Sŏngbo Munhwajae Yŏn'guwŏn 聖寶文化材研究院. The paintings and scholarly findings, published as a forty-volume series from 1996 to 2007, serve as one of the essential sources for the study of Korean Buddhist paintings. The collection also includes additional votive inscriptions examined by other scholars and the Pulgyo Munhwajae Yŏn'guso 佛教文 化財研究所.

The proposals are part of Han Yong'un's Treatise on the Restoration of Korean Buddhism (Chosŏn Pulgyo yusinnon 朝鮮佛教維 新論). This tract, together with other reform proposals by Kwŏn Sangno 權相老 (1879-1965) and Yi Yŏngjae 李英宰 (1900-1927), has been translated into English by Pori Park. For an English translation of the relevant passages, see (Gwon et al. 2016, pp. 130-34, 150-57). For a critical appraisal of Han Yong'un's treatise and activities, see (Hur 2010). For more details on Buddhist reform proposals before the March First Movement of 1919, see (Park 2009, pp. 48-68).

A case of Anyang'am for which Ch'ukyŏn produced several Buddhist paintings provides an interesting comparison. See (Ch'oe 2010; Lee 2019).

The architectural types and features of these halls have been examined in (Kim 1999; Son 2007; Kim and Chŏn 2019, pp. 31-42).

For studies of the Unmunsa 雲門寺 case, see (Kim 2007, pp. 375-95; C. Kim 2018, pp. 130-39).

Tong'a ilbo, 28 October 1924.

A modern Korean translation of the piece is published in (Ch'inil Panminjok Haengwi Chinsang Kyumyŏng Wiwŏnhoe 2009, pp. 317-20).

Maeil sinbo, 27 May 1922.

Tong'a ilbo, 9 April; 23 April; 21 May; 28 May 1921.

Members of this lay Buddhist community held powerful positions in government, business, and the media in colonial Korea. The organization was renamed the Association of Korean Buddhism (Chōsen Bukkyōdan 朝鮮佛教團) in 1925. For in-depth studies on the association, see (Yun 2017; H. Kim 2019).

See Maeil sinbo, 5 January; 14 February; 8 March; 25 March 1922. See also Tong'a ilbo, 5 January; 15 January; 5 February; 15 February; 5 March 1922.

Tong'a ilbo, 22 January 1922.

Tong'a ilbo, 10 July 1921. For the location of the school within the temple precinct, see (H. Yi 2005, pp. 183-84).

A monk surnamed Chin 陳, who worked as Yi Hoegwang's translator, stole a large sum of money. See Tong'a ilbo, 7 August 1922.

Maeil sinbo, 2 September 1923. While the property of the propagation space was under Yi Hoegwang, that of the clinic belonged to Chang Il. See Chosŏn ilbo 朝鮮日報, 29 October 1924. The clinic had to shut down due to the financial difficulties caused by Chang Il's fraud and embezzlement. See Tong'a ilbo, 3 October 1924; Chungoe ilbo 中外日報, 19 August 1927.

It is hard to fathom how appealing this was to urban residents due to the lack of supporting evidence. For a critical reassessment of propagation halls and propagators in the early colonial period, see (H. Kim 2018, pp. 239-42).

Maeil sinbo, 27 May 1922.

Maeil sinbo, 6 March 1920.

Tong'a ilbo, 7 August 1922; 28 October 1924.

Maeil sinbo, 13 February 1915.

For more on Empress Ŏm's life, see (H. Han 2006). For her patronage of Buddhist paintings, see (Yu 2014).

See (Yi 1918, vol. 2, p. 956; Kim 2012, p. 251). See also Tong'a ilbo, 25 June 1920; 7 August 1922.

For instance, she patronized the dedication of the Amitābha Buddha's Assembly (1891) and Guardian Deities (1891) of Pogwangsa 普光寺 in Kyŏnggi Province, Amitābha Buddha's Assembly (1891) of Sugu'am 守口庵, a branch temple of 
Pogwangsa, and the Ksitigarbha, Guardian Deities, and Ten Kings of Hell of Sillŭksa (1906), among others (Kogyŏng et al. 2011, pp. 612, 751, pp. 957-58). See also (Ch'oe 2012a, pp. 55-57; Yu 2015, p. 173; Ch'oe 2019, p. 97).

64 The Simgŏmdang accommodated the Ten-Thousand-Day Buddha Recitation Assembly from 1934 to 1946. It was converted to the meditation hall in 1946 but is currently used as the monks' academy (kangwŏn 講院). See (Yi 1992, pp. 614-15; Kim and Chŏn 2019, pp. 37, 41). For photographs of the two buildings, see (Munhwajaechŏng 2014a, vol. 1, pp. 276-76).

65 She is listed as the major benefactor in two records commemorating the completion of these buildings. For transcriptions of these records, see catalog entries 576 in (Pulgyo Munhwajae Yŏn'guso and Munhwajaech'ŏng 2011, p. 319) and 580 in (Pulgyo Munhwajae Yŏn'guso and Munhwajaech'ŏng 2011, p. 320). It should be noted that Lady Chŏn was a patron of Haeinsa before she met Yi Hoegwang. See catalog entry 652 in (Pulgyo Munhwajae Yŏn'guso and Munhwajaech'ŏng 2011, p. 325).

66 See catalog entry 365 in (Pulgyo Munhwajae Yŏn'guso and Munhwajaech'ŏng 2011, p. 308).

67 For her financial support for women's education, see Hwangsŏng sinmun 皇城新聞, 16 January 1910; Maeil sinbo, 19 March 1914; Tong'a ilbo, 22 March 1921.

68 Tong'a ilbo, 3 October 1924; Sidae ilbo 時代日報, 21 May 1925.

69 Sidae ilbo, 21 May 1925. See also (Ch'oe 2019).

70 Tong'a ilbo, 14 August 1924. Properties of Haeinsa faced danger of being seized. See also Tong'a ilbo, 28 October 1924. The propagation space was temporarily closed in the spring of 1924 due to the conflict between Yi Hoegwang and Yi Wŏnsŏk, a key member of the Great Meeting of Korean Buddhism, who had bought buildings of the propagation space and 300 p'yŏng of its land. See Sidae ilbo, 39 April 1925; Maeil sinbo, 2 May 1925.

71 Monks of Haeinsa appealed the Government General of Korea to dismiss Yi Hoegwang from the abbotship because of his fraudulent act. See Tong'a ilbo, 14 October 1923. Yi Hoegwang, despite his campaign to remain in office, lost his abbotship the next year. See Tong'a ilbo, 16 September 1924.

72 Maeil sinbo, 31 March 1925; Tong'a ilbo, 20 May 1925; Sidae ilbo, 21 May 1925; Maeil sinbo, 17 August 1927; Chungoe ilbo, 19 August 1927.

73 See Chōsen Sōtokufu kanpō 朝鮮總督府官報 No. 2155, 19 March 1934.

\section{References}

An, Ch'angmo (Ahn Changmo 안창모). 2009. Tŏksugung: Sidae ŭi unmyŏng ŭl an'go cheguk ŭi chungsime sŏda (덕수궁: 시대의 운명을 안 고 제국의 중심에 서다). Seoul: Tongnyŏk.

Buswell, Robert. 1993. The Zen Monastic Experience. Princeton: Princeton University Press.

Chang, P'ilgu (Chang Pilgu 장필구). 2014. 20segi chŏnban'gi Chosŏn wangsil ŭi pyŏnhwa wa Ch'angdŏkkung kŏnch'uk hwaltong ŭi sŏnggyŏk (20세기 전반기 조선왕실의 변화와 창덕궁 건축활동의 성격). Ph.D. dissertation, Seoul National University, Seoul, Korea.

Chang, P'ilgu (Chang Pilgu 장필구), and Ponghŭi Chŏn (Bong-hee Jeon 봉희 전). 2013. Kojong changnye kigan Sinsŏnwŏnjŏn ŭi chosŏng kwa Tŏksugung Ch'angdŏkkung kungyŏk ŭi pyŏnhwa (고종 장례 기간 신선원전의 조성과 덕수궁·창덕궁 궁역의 변화). Taehan kŏnch'ukakoe nonmunjip kyehoekkye (大韓建築學會論文集 計劃系) 29: 197-208.

Chang, Hee Jung, and J. Keith Wilson. 2003. The Themes and Masters of Late Chosŏn and Twentieth-Century Korean Buddhist Brush Paintings. In Drawing of Faith: Ink Paintings for Korean Buddhist Icons. Los Angeles: Dongguk University Museum and Los Angeles County Museum of Art, pp. 58-65.

Chin, Chunhyŏn (Jin Jun-hyeon 진준현). 1999. Tanwŏn Kim Hongdo yŏn'gu (단원 김홍도 연구). Seoul: Ilchisa.

Ch'inil Panminjok Haengwi Chinsang Kyumyŏng Wiwŏnhoe (친일반민족행위진상규명위원회), ed. 2009. Ch'inil panminjok haengwi kwangye saryojip XIV: Ilche kangjŏmgi chonggyogye ŭi ch'inil hyŏmnyŏk (친일반민족행위관계사료집 XIV-일제 강점기 종교계의 친 일협력-). Seoul: Ch'inil Panminjok Haengwi Chinsang Kyumyŏng Wiwŏnhoe.

Cho, Eunsu. 2003. Re-thinking Late 19th Century Chosŏn Buddhist Society. Acta Koreana 6: 87-109.

Ch'oe, Yŏp (Choi Yeob 崔燁). 2005. Kosandang Ch'ukyŏn ŭi purhwa yŏn'gu (古山堂 竺演手 佛畫 研究). Tong'ak misulsahak (東岳美術 史學) 5: 165-90.

Ch'oe, Yŏp (Choi Yeob 최 엽). 2010. 20segi chŏnban purhwa ŭi saeroun tonghyang kwa hwasŭng ŭi ipchi: Sŏul Anyang'am ŭi purhwa rŭl chungsim ŭro (20세기 전반 佛畫의 새로운 동향과 畫僧의 입지: 서울 安養庵의 佛畫를 중심으로). Misulsahak yŏn'gu (美術史學 研究) 266: 189-219.

Ch'oe, Yŏp (Choi Yeob 최 엽). 2012a. Han'guk kŭndaegi ŭi purhwa yŏn'gu (韓國 近代期의 佛畫 研究). Ph.D. dissertation, Dongguk University, Seoul, Korea.

Ch'oe, Yŏp (Choi Yeob 최엽). 2012b. Kŭndaegi Pulgyogye wa purhwa ŭi chejak (근대기 불교계와 佛畫의 제작). Tong'ak misulsahak (東 岳美術史學) 13: 269-95.

Ch'oe, Yŏp (Choi Yeob 최엽). 2014a. Han'guk kŭndaegi purhwa ŭi taejung p'ogyojŏk sŏnggyŏk (한국 근대기 佛畫의 대중 포교적 성 격). Misulsahak yŏn'gu (美術史學研究) 281: 203-28. 
Ch'oe, Yŏp (Choi Yeob 최 엽). 2014b. Yŏsu Hŭnguksa ŭi Chejon chiphoe to tosang yŏn'gu (여수 興國寺의 <諸尊集會圖> 도상 연구). Pulgyo misul (佛教美術) 25: 65-72.

Ch'oe, Yŏp (Choi Yeob 최엽). 2019. Sŭwisŭ sojae P'aju Pogwangsa Suguam hubulto yŏn'gu (스위스 소재 파주 보광사 수구암 후불도 연구). Misulsa nondan (美術史論壇) 48: 91-112.

Ch’ŏn, Ilch'ŏng (쳔 일청). 1911. Kisyŏ: Singyo puingye e iron ŭro kyŏnggo ham (긔셔: 信教婦人界에 一言으로 경고함). Chosŏn Pulgyo wŏlbo (朝鮮佛教月報) 3: 44-47.

Chŏn, Yŏnggŭn (Jeon Youngkeun 전 영근). 2016. Naesa pulsŏ wa yangan (内賜佛書와 量案). In Hwasŏng Yongjusa (화성 용주사). Edited by Cho Wŏngyo (Jo Wongyo 조원교) and Yu Kyŏnghŭi (Ryu Kyunghee 유경희). Seoul: Kungnip Chungang Pangmulgwan, pp. 166-97.

Chŏng, Chinhŭi (Jung Jinhee 정 진희). 2020. Ch'isŏnggwang yŏrae to e kŭryŏjin sinsŏn munja tosang koch'al: Sŏul Anyang'am Kŭmnyunjŏn Ch'isŏnggwang yŏrae to rŭl chungsim ŭro (熾盛光如來圖에 그려 진 神仙文字圖像 고찰一서울 안양암 금륜전 치성 광 여래도를 중심으로-). Han'guk minhwa (한국민화) 13: 138-63.

Chŏng, Myŏnghŭi (Jeong Myounghee 鄭明熙). 2016. Chosŏn sidae Pulgyo ŭisik kwa sŭngnyŏ ŭi soim pyŏnhwa: Kamno to wa munhŏn kirok ŭl chungsim ŭro (조선시대 불교의식과 승려의 소임 변화감로도와 문헌 기록을 중심으로). Misulsa yŏn'gu (美術 史研究) 31: 253-91.

Chŏng, Wut'aek (Chung Woothak 정우택). 2007. Kŭngnak segye ŭi insik kwa misul (극락 세계의 인식과 미술). In Pulgyo misul, sangjing kwa yŏmwŏn ŭi segye (불교미술, 상징 과 염 원의 세계). Edited by Kuksa P'yŏnch'an Wiwŏnhoe. Seoul: Tusan Tong'a, pp. 127-65.

Chōsen shyūkyōkai genjyō. 1926. Chōsen shyūkyōkai genjyō (朝鮮宗教界現狀). Chōsen Bukkyō (朝鮮佛教) 28: 54 .

Chōsen Sōtokufu. 1921. Chōsen: Shashinchō (朝鮮: 寫眞帖). Keijō: Chōsen Sōtokufu.

Griffis, William Elliot. 1912. A Modern Pioneer in Korea: The Life Story of Henry G. Appenzeller. New York: Fleming H. Revell.

Gwon, Sangro, Yi Yeongjae, and Han Yongun. 2016. Tracts on the Modern Reformation of Korean Buddhism. Translated and Introduced by Pori Park. Seoul: Jogye Order of Korean Buddhism.

Han, Hŭisuk (Han Heesook 한희숙). 2006. Kuhan mal Sunhŏn hwanggwibi Ŏm pi ŭi saengae wa hwaltong (구한말 순헌황귀비 엄비 의 생애와 활동). Asia yŏsŏng yŏn'gu (아시아여성연구) 45: 195-239.

Han, Tongmin (한동민). 2006. Sach'allyŏng ch'eje ŭi yŏksajŏk paegyŏng kwa ŭimi (寺刹令 체제의 역사적 배경과 의 미). In Pulgyo kŭndaehwa ŭi chŏngae wa sŏngkyŏk (불교 근대화의 전개와 성 격). Edited by Taehan Pulgyo Chogyejong kyoyukwŏn Purhak yŏn'guso (대한불교 조계종 교육원 불학연구소). Seoul: Chogyejong Ch'ulp'ansa, pp. 93-134.

Han, Yong'un. 1913. Chosŏn Pulgyo yusinnon (朝鮮佛教維新論). Kyŏngsŏng: Pulgyo Sŏgwan.

Henry, Todd A. 2007. Respatializing Chosŏn's Royal Capital: The Politics of Japanese Urban Reforms in Early Colonial Seoul, 1905-19. In Sitings: Critical Approaches to Korean Geography. Edited by Timothy R. Tangherlini and Sallie Yea. Honolulu: University of Hwaii Press, pp. 15-38.

Henry, Todd A. 2014. Assimilating Seoul: Japanese Rule and the Politics of Public Space in Colonial Korea, 1910-1945. Berkeley: University of California Press.

Hoemyŏng (晦明). 1991. Hoemyŏng munjip (晦明文集). Edited and translated by Kwŏn T'aeyŏn (권 태 연). Seoul: Yŏrae.

Hur, Nam-lin. 2010. Han Yong'un (1879-1944) and Buddhist Reform in Colonial Korea. Japanese Journal of Religious Studies 37: 75-97. [CrossRef]

Hyedam (혜담), ed. 2002. 22in ŭi chŭng'ŏn ŭl t'onghae pon kŭnhyŏndae pulgyosa (22인의 증언을 통해 본 근현대 불교사). Seoul: Sŏnu toryang Han'guk kŭnhyŏndaesa yŏn'guhoe.

Im, Hyebong (임혜봉). 2005. Ch'inil sŭngnyŏ 108in: Kkŭnnaji anŭn yŏksa ŭi murŭm (친일 승려 108 인: 끝나지 않은 역사의 물음). P'aju: Ch'ŏngnyŏnsa.

Kagan (覺岸). 1941. Tongsa yŏlchŏn (東師列傳). Kyŏngsŏng: Chosŏnsa P'yŏnsuhoe.

Kang, Sŏkju (강석주), and Kyŏnghun Pak (경훈박). 2002. Pulgyo kŭnse paengnyŏn (불교근세 백 년). Seoul: Minjoksa.

Kang, Soyŏn (Kang Soyon 강소 연). 2010. Kang Soyŏn ŭi misulsa kihaeng (9): Chŏnt'ong purhwa ŭi ch'angjojŏk chaehyŏn Ilsim samgwanmun t'aeng (강소연의 미술사기행(9): 전통불화의 창조적 재현 <一心三關門幀>). Munhak/Sahak/Ch'orrak (문학/사학/철 학) 23/24: 166-84.

Kang, Soyŏn (Kang Soyon 강소연). 2015. Yŏngga ch'ŏndo ŭi tosang haesŏk 'pyŏngnyŏn tae wa wŏnsang': Chosŏn hugi kamno to wa kŭngnak kup'um to rŭl chungsim ŭro (靈駕薦度의 도상해석 '碧蓮臺와 圓相'一조선후기 甘露圖과 極樂九品圖를 중심으로一). Han'guk pulgyohak (韓國佛教學) 73: 341-82.

Kim, Chihŏn (Kim Gee-heon 김지헌), and Ponghŭi Chŏn (Bong-hee Jeon 봉희 전). 2019. 19segi wa 20segi ch'o yŏmbultang ŭi suyong (19세기와 20세기 초 念佛堂의 수용). Kŏnch'uk yŏksa yŏn'gu (건축역사연구) 28: 31-42.

Kim, Chiyŏn (Kim Jiyeon 김지 연). 2014a. Chosŏn hugi panya yongsŏn to yŏn'gu (朝鮮後期般若龍船圖 研究). Misulsahak yŏn'gu (美術 史學研究) 281: 97-113.

Kim, Chŏngdong (김 정동). 2004. Kojong hwangje ka saranghan Chŏngdong kwa Tŏksugung (고종황제가 사랑한 정동과 덕수궁). Seoul: Parŏn.

Kim, Chŏngdong (김 정동). 2014b. Tŏksugung Sŏnwŏnjŏn yŏngyŏk ŭi yŏksa wa kojŭng yŏn'gu (덕수궁 선원전 영 역의 역사와 고증 연구). In Tŏksugung Sŏnwŏnjŏn pogwŏn chŏngbi kibon kyehoek (덕수궁 선원 전 복원 정비 기본계획). Edited by Munhwajaechŏng. Taejŏn: Munhwajaechŏng, pp. 78-199.

Kim, Chŏnghŭi (Kim Junghee 김정희). 2018. Chosŏn hugi Unmunsa ŭi purhwa wa pulsa (조선 후기 운문사의 佛事와 불화). Kangjwa misulsa (講座美術史) 50: 109-49. 
Kim, Hwansoo Ilmee. 2012. Empire of the Dharma: Korean and Japanese Buddhism, 1877-1912. Boston: Harvard University Asia Center. Kim, Hwansoo Ilmee. 2018. The Korean Buddhist Empire: A Transnational History, 1910-1945. Boston: Harvard University Asia Center.

Kim, Hwansoo Ilmee. 2019. Who Gets to Represent Korean Buddhism? The Contest to Control Buddhism in Colonial Korea, 1920-45. The Journal of Japanese Studies 45: 339-68. [CrossRef]

Kim, Hyogyŏng (金孝敬). 1933. Chōsen ni okeru shinkō no genjyō (朝鮮に於ける信仰狀態の現狀). Chōsen Bukkyō (朝鮮佛教) 92: 14-15.

Kim, Kijŏn (金起田). 1924. Chae Kyŏngsŏng kak kyohoe ŭi ponbu rŭl yŏkbanghago (在京城 各教會의 本部를 歷訪하고). Kaebyŏk (開 闢) 48: 71-79.

Kim, Kwangsik (Kim Gwangsik 金光植). 1995. 1910nyŏndae Pulgyogye ŭi Chodongjong maengyak kwa Imejojong undong (1910年代 佛教界의 曹洞宗 盟約과 臨濟宗 運動). Han'guk minjok undongsa yŏn'gu (한국 민족운동사연구) 12: 97-127.

Kim, Kwangsik (Kim Gwangsik 김 광식). 2003. Kakhwangsa ŭi sŏllip kwa unyŏng: Kŭndae Pulgyo ch'oech'o ŭi p'ogyodang yŏn'gu (각황사의 설립과 운영-근대불교 최초의 포교당 연구一). Taegak sasang (大覺思想) 6: 9-49.

Kim, Kyŏngjip (김경집). 1998. Han'guk kŭndae Pulgyosa (한국근대불교사). Seoul: Kyŏngsŏwŏn.

Kim, Migyŏng (Kim Migyeong 김미경). 2007. 19segi Manil yŏmbulhoe ŭi sŏnghaeng kwa Unmunsa purhwa (19세기 萬日念佛會의 성 행과 雲門寺 불화). Pulgyo misulsahak (佛教美術史學) 5: 375-95.

Kim, Paekyŏng (Kim Baek Yung 김 백 영). 2009. Chibae wa konggan: Singminji tosi Kyŏngsŏng kwa cheguk Ilbon (지 배와 공간: 식민지도시 경성과 제국 일본). Seoul: Munhak Kwa Chisŏngsa.

Kim, Sŏngdo (김성도). 1999. Chosŏn sidea mal kwa 20segi chŏnbangi ŭi sach'al kŏnch'ŭk t’ŭksŏng e kwanhan yŏn'gu: Sŏul, Kyŏnggi irwŏn ŭi pulchŏn ŭl chungsim ŭro (朝鮮時代末과 20世紀前半期의 寺刹 建築 特性에 關한 研究: 서울·경기 일원의 佛殿을 중심으 로). Ph.D. dissertation, Korea University, Seoul, Korea.

Kim, Sŏngsun (Kim Sung-soon 김성순). 2019. Chosŏn hugi yŏmbul kyŏlsa ŭi suhaeng munhwa koch'al: Chaegaja ŭi ch'amyŏ e ttarŭn yŏnghyang ŭl chungsim ŭro (조선후기 염불결사의 수행문화 고찰: 재가자의 참여에 따른 영향을 중심으로). Chŏngt'ohak yŏn'gu (淨土學研究) 32: 245-69.

Kim, Sunsŏk (Kim Sunseok 金淳碩). 1994. Kaehanggi Ilbon Pulgyo chongp'adŭl ŭi Han'guk ch'imt'u": Ilbon sach'al kwa pyŏrwŏn mit

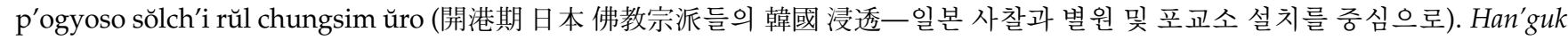
tongnip undongsa yŏn'gu (한국독립 운동사연구) 8: 127-50.

Kim, Yongsuk (김용숙). 1987. Chosŏn cho kungjung p'ungsok yŏn'gu (朝鮮朝宮中風俗 研究). Seoul: Ilchisa.

Kim, Yunjŏng (Kim Yoonjeong 김윤정), Sŏ Ch'isang (Seo Chisang 서치상), and Yi Mina (Lee Mina 이미나). 2012. Kaehang ihu Ilbon Pulgyo ŭi ch'imtŭ e ttarŭn sawŏn ŭi kŏllip kwa kŏnch'uk t'ŭksŏng kaegwan (개항 이후 일본불교의 침투에 따른 사원의 건립과 건축특성 개관). Kŏnch'uk yŏksa yŏn'gu (건축역사연구) 21: 53-74.

Koam (고암). 1990. Chabi posal ŭi kil (慈悲菩薩의 길). Seoul: Pulgyo Yŏngsanghoebosa.

Kogyŏng (고경), Songch'ŏn (송천), Yi Chongsu (이종수), Hŏ Sangho (허상호), and Kim Chŏngmin (김 정 민), eds. 2011. Han'guk ŭi purhwa hwagijip (韓國의 佛畫 畫記集). Yangsan: Sŏngbo Munhwajae Yŏn'guwŏn.

Kungnip Kongju Pangmulgwan (국립공주박물관). 2012. Magoksa kŭndae purhwa rŭl mannada (마곡사 근대불화를 만나다). Kongju: Kungnip Kongju Pangmulgwan.

Kwŏn, Sangno (權相老). 1917. Chosŏn Pulgyo yaksa (朝鮮佛教略史). Kyŏngsŏng: Sinmungwan.

Lee, Seunghye. 2019. Aspirations for the Pure Land Embodied in a Modern Korean Temple, Anyang'am. Acta Koreana $22:$ 35-59.

Lee, Seunghye. 2021. Korea's First Museum and the Categorization of “Buddhist Studies”. Sungkyun Journal of East Asian Studies 21: 51-81.

Mun, Myŏngdae (Moon Myung-dae 문명대). 2019. Chosŏn malgi (19segi, Sunjong Sunjogi) Kŭngnak kup'um to ŭi tosanghak (조선 말 기[19세기, 순종 순조기] 極樂九品圖의 圖像學). Kangjwa misulsa (講座美術史) 52: 331-43.

Munhwajaechŏng (문화재청). 2014a. Hapch'ŏn Haeinsa chŏngmil silch'ŭk chosa pogosŏ (합천 해인사 정 밀실측조사보고서). 2 vols, Taejŏn: Munhwajaechŏng.

Munhwajaechŏng (문화재청). 2014b. Tŏksugung Sŏnwŏnjŏn pogwŏn chŏngbi kibon kyehoek (덕수궁 선원전 복원정비 기본계획). Taejŏn: Munhwajaechŏng.

Nathan, Mark A. 2018. From the Mountains to the Cities: A History of Buddhist Propagation in Modern Korea. Honolulu: University of Hawaii Press.

Oda, Shōgo (小田省吾). 1938. Tokujukyūshi (德壽宮史). Keijō: Riōshoku.

Pak, Chŏngae (Park Jeongae 박정 애). 2006. Yongjusa pon Pumo ŭnjung kyŏng p'anhwa wa Chosŏn hugi hoehwa (龍珠寺本 父母恩重經 版畫와 朝鮮後期 繪). Pulgyo misulsahak (佛教美術史學) 4: 162-95.

Park, Pori. 2009. Trial and Error in Modernist Reforms: Korean Buddhism under Colonial Rule. Berkeley: University of California Press.

Pulgyo Chungang Pangmulgwan (불교중앙박물관). 2016. Kkumkkunnŭn chŭlgŏum, kŭngnak (꿈꾸는 즐거움, 극락). Seoul: Pulgyo Chungang Pangmulgwan.

Pulgyo Chungang Pangmulgwan (불교중앙박물관). 2020. Hyosim ŭro nat'un pulsim ŭi segye: Hwasan Yongjusa (효심으로 나툰 불심의 세계: 花山 용주사). Seoul: Pulgyo Chungang Pangmulgwan.

Pulgyo Munhwajae Yŏn'guso (불교문화재연구소), and Munhwajaech'ŏng (문화재청). 2011. Han'guk ŭi sach'al munhwaje: Chŏn'guk sach'al munhwajae ilche chosa Kyŏngsangnamdo III Charyojip (한국의 사찰문화재: 전국사찰문화재일제조사 경상남도 III 자료집). Seoul: Pulgyuo Munhwajae Yŏn'guso.

P’yŏn, Muyŏng (편무영). 2002. Ch'op'ail minsongnon (초파일민속론). Seoul: Minsogwŏn. 
Samp'ung enjiniŏring kŏnch'uk samuso (삼풍엔지니어링 건축사무소), ed. 2005. Tŏksugung: Pogwŏn, chŏngbi kibon kyehoek (德壽宮: 復 元·整備 基本計劃). 2 vols, Taejŏn: Munhwahaech'ŏng.

Shin, Sŏnyŏng (Shin Sun-young 신선 영). 2014. Kaehanggi ‘Kim Hongdo p'ungsokhwa' ŭi mobang kwa hwaksan (개항기 ‘김홍도 풍속 화’의 모방과 확산). Misulsahak yŏn'gu (美術史學研究) 283/284: 115-42.

Sŏ, Chaeyŏng (Seo Jaeyeong 서재 영). 2006. Sŭngnyŏ ŭi ipsŏng kŭmji haeje wa kŭndae Pulgyo ŭi chŏn'gae (승려의 입성금지 해제와 근 대불교의 전개). Pulgyo hakpo (佛教學報) 45: 37-65.

Sŏ, Kyŏngsu (徐景洙). 1973. Han'guk Pulgyo paengnyŏnsa (韓國 佛教 百年史). Sŏnggok nonch'ong (省谷論叢) 4: 37-78.

Sŏkjŏng (石鼎). 1997. Haeinsa ponmalsa ŭi t’aenghwa (II) (海印寺 本末寺의 幀畫). In Han'guk ŭi purhwa (韓國의 佛畫). Edited by Sŏngbo Munhwajae Yŏn'guwŏn (聖寶文化財研究院). Yangsan: Sŏngbo Munhwajae Yŏn'guwŏn, vol. 5, pp. 225-30.

Son, Sinyŏng (Shon Shinyoung 손신 영). 2007. 19segi Pulgyo kŏnch'uk ŭi yŏn'gu: Sŏul, Kyŏnggi chiyŏk ŭl chungsim ŭro (19世紀 佛教 建築의 研究: 서울·경기지 역을 중심으로). Ph.D. dissertation, Dongguk University, Seoul, Korea.

Sŏngbo Munhwajae Yŏn'guwŏn (聖寶文化財研究院), ed. 1997. Han'guk ŭi purhwa (韓國의 佛畫). Vol. 5 Haeinsa ponmalsa p'yŏn (ha) (海 印寺 本末寺篇[下]). Yangsan: Sŏngbo Munhwajae Yŏn'guwŏn.

Taehan Pulgyo Chogyejong (대한불교조계종). 1998. Algi swiun Han'guk Pulgyo kŭnsesa (알기 쉬운 한국불교 근세사). Seoul: Chogyejong Kirrokwan.

Tŏksugung Kwalliso (덕수궁관리소), ed. 2020. Taehan cheguk hwangje ŭi kunggwŏl (대한제국 황제의 궁궐). Seoul: Tŏksugung Kwalliso.

U, Tongsŏn (우동선), and Sŏngjin Pak (성 진박), eds. 2009. Kunggwŏl ŭi nunmul, paengnyŏn ŭi chi'immuk (궁궐의 눈물, 백 년의 침묵). P'aju: Hyohyŏng Ch'ulp'an.

Walraven, Boudewijn. 2000. Religion and the City: Seoul in the Nineteenth Century. The Review of Korean Studies 3: 178-206.

Yi, Chigwan (李智冠), ed. 1992. Haeinsa chi (海印寺誌). Seoul: Kasan Mun'go.

Yi, Hoegwang (李晦光). 1921. Chōsen Bukkyō no kakusei to shakai jigyō (朝鮮佛教の覺醒と社會事業). Chōsen (朝鮮) 77: 61-65.

Yi, Hyewŏn (이혜 원). 2005. Kyŏngun'gung kungyŏk ŭi pyŏnch'ŏn (경 운 궁 궁 역의 변 천). In Tŏksugung: Pogwŏn, chŏngbi kibon kyehoek (德壽宮: 復元·整備 基本計劃). Edited by Samp'ung enjiniŏring kŏnch'uk samuso (삼풍 엔지니어링 건축사무소). Taejŏn: Munhwahaech'ŏng, vol. 1, pp. 63-79.

Yi, Kanggŭn (이강근). 2005. Tŏksugung Sŏnwŏnjŏn pogwŏn ŭi che munje (덕수궁 咟源殿 복원의 제문제). Kŏnch'uk yŏksa yŏn'gu (建築 歷史研究) 14: 203-8.

Yi, Nŭnghwa (李能和). 1918. Chosŏn Pulgyo t'ongsa (朝鮮佛教通史). 2 vols, Kyŏngsŏng: Sinmun'gwan.

Yi, Sŏngsi (Lee Sungsi 이성시). 2004a. Chosŏn wangjo ŭi sangjing konggan kwa pangmulgwan (조선왕조의 상징공간과 박물관). In Kuksa ŭi sinhwa rŭl nŏmŏsŏ (국사의 신화를 넘어서). Edited by Im Chihyŏn (Lim Jie-hyun 임지현) and Yi Sŏngsi (Lee Sungsi 이성 시). Seoul: Hyumŏnisŭt'ŭ, pp. 265-95.

Yi, Sŭnghye (Lee Seunghye 李勝慧). 2005. Kŭndae purhwasŭng ŭi sŏyanghwapŏp suyong yŏn'gu (近代 佛畫僧手 西洋畫法受容 研究). Master's thesis, Seoul National University, Seoul, Korea.

Yi, Sunu (이순우). 2004b. T'erauch'i ch'ongdok, Chosŏn ŭi kkochi toeda (테라우치 총독, 조선의 꽃이 되다). Seoul: Hanŭljae.

Yi, Yŏnghwa (이영화). 2005a. Ilche sigi wa hyŏndae ŭi Tŏksugung pyŏnhyŏng (일제시기와 현대의 덕수궁 변형). In Tŏksugung: Pogwŏn, chŏngbi kibon kyehoek (德壽宮: 復元·整備 基本計劃). Edited by Samp'ung enjiniŏring kŏnch'uk samuso (삼풍엔지니어 링 건축사무 소). Taejŏn: Munhwahaech'ŏng, vol. 1, pp. 63-79.

Yi, Yongyun (Lee Yongyun 李容胤). 2013. Chosŏn hugi Kyŏngsangdo chiyŏk esŏ chejaktoen Kwan gyŏng sibyukkwan pyŏnsang to wa yŏmbulsŏn (조선 후기 경상도 지역에서 제작된 觀經十六觀變相圖와 念佛禪). Misulsa nondan (美術史論壇) 36: 61-90.

Yi, Yŏnno (이연노). 2005b. Ilche kangjŏmgi Kyŏngun'kung ŭi kŏnch'ukchŏk pyŏnhwa (일 제 강 점 기 경 운궁의 건축적 변화). In Tŏksugung: Pogwŏn, chŏngbi kibon kyehoek (德壽宮: 復元·整備 基本計劃). Edited by Samp'ung enjiniŏring kŏnch'uk samuso (삼풍 엔지니어링 건축사무소). Taejŏn: Munhwahaech'ŏng, vol. 1, pp. 137-69.

Yŏm, Pokgyu (Yum Bokkyu 염복규). 2016. Sŏul ŭi kiwŏn Kyŏngsŏng ŭi t'ansaeng: 1910-1945 tosi kyehoek ŭro pon Kyŏngsŏng ŭi yŏksa (서울 의 기원 경성의 탄생: 1910-1945 도시계획으로 본 경성의 역사). Seoul: Idea.

Yu, Kyŏnghŭi (Ryu Kyunghee 유경희). 2014. Kojongdae Sunhŏn hwanggwibi Ŏmssi parwŏn purhwa (高宗代 純獻皇貴妃 嚴氏 發願 불화). Misul charyo (美術資料) 86: 111-36.

Yu, Kyŏnghŭi (Ryu Kyunghee 유경희). 2015. Chosŏn malgi wangsil parwŏn purhwa yŏn'gu (조선 말기 王室發願 佛畫 연구). Ph.D. dissertation, The Academy of Korean Studies, Gyeonggi-do, Korea.

Yun, Kiyŏp (Yoon Ki-yeop 윤기 엽). 2017. Ilche kangjŏmgi Chōsen Bukkyōdan ŭi yŏnwŏn kwa sachŏk pyŏnch'ŏn: Chōsen Bukkyōdan imwŏnjin ŭi kusŏng kwa iryŏk ŭl chungsim ŭro (일제강점기 朝鮮佛教團의 연원과 史的 변천—조선불교단 임원진의 구성과 이력 을 중심으로). Taedong munhwa yŏn'gu (대동문화연구) 97: 293-322. 